\title{
Analysis of protein composition and protein expression in the tear fluid of patients with congenital aniridia
}

\author{
Robert Ihnatko, Ulla Edén, Neil Lagali, Anette Dellby and Per Fagerholm
}

\section{Linköping University Post Print}

\section{Tweet}

N.B.: When citing this work, cite the original article.

Original Publication:

Robert Ihnatko, Ulla Edén, Neil Lagali, Anette Dellby and Per Fagerholm, Analysis of protein composition and protein expression in the tear fluid of patients with congenital aniridia, 2013, Journal of Proteomics, (94), 78-88.

http://dx.doi.org/10.1016/i.jprot.2013.09.003

Copyright: Elsevier

http://www.elsevier.com/

Postprint available at: Linköping University Electronic Press

http://urn.kb.se/resolve?urn=urn:nbn:se:liu:diva-104841 


\title{
Analysis of protein composition and protein expression in the tear fluid of patients with congenital aniridia
}

\author{
Robert Ihnatko*, Ulla Eden, Neil Lagali, Anette Dellby, and Per Fagerholm
}

Integrative Regenerative Medicine Centre and Department of Clinical and Experimental Medicine, Faculty of Health Sciences, Linköping University, 58185 Linköping, Sweden

Running title: Proteomic analysis of tear fluid in aniridia patients

Keywords: aniridia, keratopathy, tear fluid, two-dimensional electrophoresis, LC-MS/MS, a-enolase

4992 words; 49 references; 3 figures; 3 tables

This work was supported by funds from The Swedish Research Council, The Country of Östergötland and Kronprinsessan Margaretas Arbetsnämnd.

The authors declare no conflict of interest.

${ }^{*}$ Corresponding author: Department of Clinical and Experimental Medicine, Faculty of Health Sciences, Linköping University, S-581 85 Linköping, Sweden. Phone: +46 101033 289; E-mail: robert.ihnatko@liu.se (R. Ihnatko) 


\section{Abstract}

Aniridia is a rare congenital genetic disorder caused by haploinsuffiency of the PAX6 gene, the master gene for development of the eye. The expression of tear proteins in aniridia is unknown. To screen for proteins involved in the aniridia pathophysiology, the tear fluid of patients with diagnosed congenital aniridia was examined using two-dimensional electrophoresis (2-DE) and liquid chromatography-tandem mass spectrometry (LC-MS/MS). Two-dimensional map of tear proteins in aniridia has been established and 7 proteins were differentially expressed with $P<0.01$ between aniridia patients and control subjects. Five of them were more abundant in healthy subjects, particularly a-enolase, peroxiredoxin 6 , cystatin S, gelsolin, apolipoprotein A-1 and two other proteins, zinc- $\alpha 2$-glycoprotein and lactoferrin were more expressed in the tears of aniridia patients. Moreover, immunoblot analysis revealed elevated levels of vascular endothelial growth factor (VEGF) in aniridia tears which is in concordance with clinical finding of pathological blood and lymph vessels in the central and peripheral cornea of aniridia patients. The proteins with different expression in patient tears may be new candidate molecules involved in the pathophysiology of aniridia and thus may be helpful for development of novel treatment strategies for the symptomatic therapy of this vision threating condition.

Highlights: • Tear proteome of patients with congenital aniridia was analyzed. • Two-dimensional map of tear proteins in aniridia was established. - The relative abundance of some of the tear proteins was altered in aniridia patients. - These proteins may be new candidate molecules involved in aniridia pathophysiology.

\section{Biological significance}

This study is first to demonstrate protein composition and protein expression in aniridic tears and identifies proteins with different abundance in tear fluid from patients with congenital aniridia vs. healthy tears. 


\section{Introduction}

Aniridia is a severe congenital panocular disorder affecting the cornea, anterior chamber, iris, lens, retina, macula and optic nerve. It occurs as a result of haploinsufficiency in paired box gene PAX6 which is responsible for a proper eye development. The alterations in retina and development of glaucoma, cataract and keratopathy lead to a progressive deterioration of the visual acuity [1]. The underdeveloped iris and retina are examples of developmental defects. Other signs as glaucoma and cataract can be either congenital or develop after birth.

Aniridia associated keratopathy (AAK) typically develops in late childhood or later in life. The reason for this debilitating condition has been attributed to malfunctioning of the corneal epithelial stem cells visualized by a progressive deterioration of the stem cell environment, the palisades of Vogt [2-5]. The break-down of the stem cell niche triggers conjunctivalisation and eventually opacification of the cornea [6]. The AAK reduces visual performance further and adds a chronic irritation and photophobia to the symptoms [7]. However, the reason for the development of AAK in patients is still unclear. Of special interest was to establish if surgical procedures triggered the AAK progression. The results however have been inconclusive due to the small amount of material and to the fact that surgery has developed towards less traumatic procedures [8].

It has been shown [9] that vascular endothelial growth factor (VEGF) and its receptors are involved in the maintenance of the stem cell barrier preventing blood vessels to enter the corneal surface. VEGF is also known to influence nerve growth $[10 ; 11]$ which may be a contributing factor to PAX6 since the dosage of PAX6 itself is the main factor contributing to pathological pattern of corneal innervation in aniridia [12]. It has also been suggested [13] that nerve growth factor receptor TrkA is involved in the regulation of the normal stem cell turnover.

The expression levels of the proteins mentioned above in patient tears with aniridia are unknown. It was thus of interest to find out if these proteins and also other protein components of tear fluid were expressed differently in tears from eyes with aniridia compared to normal controls. In the present study, for the first time, we implemented 2-DE based comparative proteomics and 1- or 2dimensional western blot for the analysis of changes in tear proteome in aniridia. The findings may help to identify molecules which can be useful for development of novel treatment strategies in 
symptomatic therapy of aniridia affected eyes. Thus, proteins with different abundance in tears between aniridia patients and healthy tears were identified.

\section{Material and methods}

\section{Participants}

A total 18 participants, 10 patients (20 eyes) with congenital aniridia from a well characterized Swedish cohort of patients (reviewed in [8]) and 16 eyes that belong to 5 healthy family members without PAX6 mutation (aniridia) or any other ocular diseases and 3 healthy volunteers that belong to the same ethnic group of Caucasian as the other individuals were included in the present study. In order to obtain the best matched patients' samples with controls, the samples in the control group were collected from individuals with the identical genetic background as in the patient group. Therefore similar number of samples used as controls for the patient group was collected inviting healthy family members without aniridia or other eye diseases. In that regard additional parameters, such as age, gender, past and current diagnoses of ocular infection or other ocular pathologies and medication were considered. Due to rare prevalence of aniridia in population it was difficult to obtain larger coherent cohort of patients and even control samples from individuals with that genetically identical background mentioned. Ethical approval was obtained from ethics committee of University Hospital at Linkoping University (Linkoping, Sweden) and informed consent was obtained from all participants prior to sample collection. The work described in this article has been carried out in accordance with the Declaration of Helsinki.

Tear sample collection and extraction of proteins from Schirmer's strips

Tear fluid from left and right eye of ten patients $(n=10)$ with diagnosed aniridia and group of 8 healthy individuals $(n=8)$, as described above, was collected using standard Schirmer's strips during clinical examination. Tear collection using Schirmer's strips was chosen as the most convenient method of sample collection for its reproducibility validated by several proteomic studies [14-17]. This method is 
capable to provide high number of identified tear proteins with function in diverse processes, such as antioxidants, protein-folding proteins, proteins involved in the metabolism, immune response, and also proteins which can be used for the classification of cell structures (reviewed in [17]). Moreover, the Schirmer's test provided important clinical data for the assessment of tear production, thus helping to exclude the samples from individuals with secondary eye pathologies, such as dry eye syndrome. The exclusion criteria in both groups were a Schirmer's test of less than $10 \mathrm{~mm}$ of moisture on the strip in 5 min, a current diagnosis of ocular infection, history of ocular or eyelid pathologies with exception of aniridia in the patient group, and the use of current ocular or systemic medication. Congenital aniridia is an inherited disease therefore disease duration for the each patient is identical with the patient's age. The clinical data for each patient and healthy individual, if applicable, along with age, gender, and ethnicity are listed in Table 1. After sample collection, wet Schirmer's strips with absorbed tears were immediately snap frozen and kept at $-80 \stackrel{\circ}{\circ}$ to prevent protein degradation until analyzed. Before analysis, proteins absorbed on Schirmer's strips were extracted with $100 \mu \mathrm{l}$ of solubilization buffer containing $20 \mathrm{mM}$ Tris, $7 \mathrm{M}$ urea, $2 \mathrm{M}$ thiourea, $0.1 \%$ CHAPS, $10 \mathrm{mM}$ 1,4-dithioerythritol (SigmaAldrich Sweden AB, Stockholm, Sweden), 0.5\% ampholytes 3-10 (Bio-Rad Laboratories, Hercules, CA, USA), and protease inhibitor cocktail (Complete mini, Roche Diagnostics Scandinavia AB, Stockholm, Sweden) and sonicated three-times for $30 \mathrm{sec}$, followed by additional incubation for $2 \mathrm{~h}$ on ice. After centrifugation $\left(15,000 \times \mathrm{g}, 30 \mathrm{~min}, 4^{\circ} \mathrm{C}\right)$, which removed debris, the samples were desalted using $3 \mathrm{kDa}$ cut-off centrifugal filter units (Millipore Ireland, Cork, IRL). The final sample volume was adjusted to $100 \mu \mathrm{l}$ with the sample buffer (20 mM Tris, $7 \mathrm{M}$ urea, $2 \mathrm{M}$ thiourea, $4 \%$ CHAPS, $10 \mathrm{mM}$ 1,4-dithioerythritol (Sigma-Aldrich), 0.5\% ampholytes 3-10 (Bio-Rad), and protease inhibitor cocktail (Complete mini) and the protein content was determined using the Bradford reagent (Pierce, Thermo Scientific, Rockford, IL, USA).

\section{Two-dimensional electrophoresis}

Isoelectric focusing (IEF) was carried out using ready-to-use immobilized pH gradient (IPG) strips (17 $\mathrm{cm}$ ) with nonlinear $\mathrm{pH}$ range IPG 3-10 NL (Bio-Rad). The individual samples (50 $\mu \mathrm{g}$ of proteins) were loaded during rehydration of IPG strips in $300 \mu$ (total volume) of IEF buffer (7 M urea, $2 \mathrm{M}$ thiourea, 4 \% CHAPS, 10 mM 1,4-dithioerythritol, $1.25 \%$ IPG buffer pH 3-10 and traces of bromophenol blue, 
Sigma-Aldrich) for $18 \mathrm{~h}$. IEF was carried out for a total $60 \mathrm{kVh}(50 \mu \mathrm{A} / \mathrm{IPG}$ strip) using Multiphor II system (Pharmacia Biotech, Uppsala, Sweden). After IEF, the strips were stored at $-80 \stackrel{\circ}{C}$ until run in the second dimension (SDS-PAGE). Prior to SDS-PAGE, the IPG strips were incubated in equilibration (EQ) solution [(6 M urea, $0.375 \mathrm{M}$ Tris-HCl pH 8.8, 2 \% SDS, 20 \% glycerol (SigmaAldrich) containing $2 \%$ dithiothreitol (DTT, Sigma-Aldrich)] and subsequently in EQ solution containing $2.5 \%$ iodoacetamide (Sigma-Aldrich) for 15 minutes each and immediately applied on the top of $13 \%$ polyacrylamide gels $(200 \times 200 \mathrm{~mm})$. SDS-PAGE was performed using Protean Plus Dodeca cell (Bio-Rad) at $15 \mathrm{~mA} / \mathrm{gel}$ for the first $1 \mathrm{~h}$ followed by $30 \mathrm{~mA} / \mathrm{gel}$ for the rest of the separation.

Image Capture Spot Quantitation and Statistical Analysis

Gels were fixed in $50 \%$ methanol, $7 \%$ acetic acid (Sigma-Aldrich) for $2 \mathrm{~h}$ followed by staining with SYPRO Ruby (Bio-Rad) for $12 \mathrm{~h}$. Excessive dye was removed by incubation of gels in solution containing $10 \%$ methanol, $7 \%$ acetic acid and gels were scanned and the images were captured as 16-bit TIFF files for further analysis. The experimental dataset comprised of 36 two-dimensional gel images of tear fluid proteome from 36 eyes divided into patient group (20 eyes) and control group consisting of healthy individuals (16 eyes). Two gel images (obtained from two tear samples (left and right eye of the patient A4) were excluded from analysis due to remarkable different protein pattern caused probably by arterial leakage. Analysis of the gel images, including background subtraction, spot volume normalization, and differences in protein expression among the groups, was performed using PDQuest 8.01 software (Bio-Rad). All images were visually inspected for artifactual spots, and merged or missed spots. Each matched spot was manually inspected and confirmed on each individual gel. For the statistical analysis, the only spots which were present in all gels from the same group were included. The amount of protein in a spot was normalized in each gel by dividing the raw quantity of each spot by the total intensity value of all the pixels in the image. The normalized spot volume is referred to as abundance. Data are presented as mean \pm SEM. The Anderson-Darling test of normality [18] was used to find the data that differed from normal distribution. Statistical differences between the groups were assessed using the Student's $t$-test or the Mann-Whithey test with $P<0.01$ considered as significant. The Mann-Whitney test was used for cases where data were not normally 
distributed. The statistical analysis was performed with commercial software SYSTAT 11 (Chicago, IL, USA). The Pearson correlation between proteomic data and clinical parameters for the patient group was performed with software Excel 2010 (Microsoft Inc., Redmond, WA, USA).

In-gel digestion and mass spectrometric identification

Excised protein spots from SYPRO Ruby stained gels were destained with $100 \mathrm{mM}$ ammonium bicarbonate in $50 \%$ acetonitrile (AcN, Sigma-Aldrich), washed with $100 \% \mathrm{AcN}$ and dried on SpeedVac (Christ, Osterode am Harz, Germany). In-gel reduction and alkylation reactions were carried out with $10 \mathrm{mM}$ DTT in $100 \mathrm{mM} \mathrm{NH}_{4} \mathrm{HCO}_{3}\left(45 \mathrm{~min}, 56^{\circ} \mathrm{C}\right.$ ) and subsequently with $50 \mathrm{mM}$ iodoacetamide in $100 \mathrm{mM} \mathrm{NH}_{4} \mathrm{HCO}_{3}\left(30 \mathrm{~min}\right.$ in the dark, $\left.20^{\circ} \mathrm{C}\right)$. Dried gel pieces were incubated in solution containing $0.1 \mu \mathrm{g}$ of sequencing grade modified trypsin (Promega, Madison, WI, USA) in 40 $\mathrm{mM} \mathrm{NH}_{4} \mathrm{HCO}_{3} / 10 \% \mathrm{AcN}$ for 20 hours at $37^{\circ} \mathrm{C}$. Extraction of the resulting peptides was performed with $2 \%$ formic acid (FA) in AcN (Sigma), and twice with $100 \% \mathrm{AcN}$ for $30 \mathrm{~min}$ at room temperature. The extracted peptides were dried on SpeedVac (Christ) and dissolved in $5 \mu \mathrm{l} 0.1 \% \mathrm{FA}$ in $50 \%$ AcN. The resulting peptide mixtures were analyzed by LC-MS/MS using nano-flow HPLC system (EASY$\mathrm{nLC}$; Bruker Daltonics, Bremen, Germany) on a $20 \mathrm{~mm} \times 100 \mu \mathrm{m}$ (particle size $5 \mu \mathrm{m}$ ) C18 pre-column followed by a $100 \mathrm{~mm} \times 75 \mu \mathrm{m} \mathrm{C18} \mathrm{column} \mathrm{(particle} \mathrm{size} 5 \mu \mathrm{m}$ ) at a flow rate $300 \mathrm{nl} / \mathrm{min}$, using a linear gradient starting with $0.1 \% \mathrm{FA}$ (solvent $\mathrm{A}$ ) and ending with $0.1 \% \mathrm{FA}$ in $100 \% \mathrm{AcN}$ (solvent B) for 45 min. The HTCultra PTM Discovery System (Bruker Daltonics, Bremen, Germany) was used for data acquisition. Raw data from tandem MS analyses were processed using DataAnalysis 3.4 software (Bruker Daltonics) and the resulting Mascot generic files were used for the search in NCBI protein database on the Mascot server (www.matrixscience.com). The search parameters were: Taxonomy: "Homo sapiens"; Enzyme: trypsin with permission of one missed cleavage site; Fixed modification: "Carbamidomethyl (C)"; Variable modifications: "Protein acetylation" and "Oxidation (M)"; Peptide tolerance: $\pm 0.8 \mathrm{Da}$ for MS data and $\pm 0.8 \mathrm{Da}$ for MS/MS data. The significance threshold for MASCOT ion identification was set to $P<0.05$. Proteins with at least one peptide passing the required bold red criteria were considered to be positively matched. 
Due to limited protein concentration in tears as well as the limited availability of aniridia patients, for the immunoblot analysis of VEGF, NGF, and TrkA we prepared pooled samples from the same patients and control samples as were used in 2-DE proteomic analysis. These pooled samples were prepared as follows: control sample $1 \mathrm{a}$ ( $30 \mu \mathrm{g}$ of proteins) by pooling of the equal quantity $(7.5 \mu \mathrm{g}$ of proteins) of the each individual sample from the controls C1-C4 (4 individuals), control sample $1 \mathrm{~b}$ (30 $\mu \mathrm{g}$ of proteins) by pooling of the equal quantity $(7.5 \mu \mathrm{g}$ of proteins) of the each individual sample from the controls $\mathrm{C} 5-\mathrm{C} 8$ ( 4 individuals), patient sample $2 \mathrm{a}$ ( $30 \mu \mathrm{g}$ of proteins) by pooling of the equal quantity ( $10 \mu \mathrm{g}$ of proteins) of the each individual sample from the patients A1-A3 (3 individuals), and patient sample $2 \mathrm{~b}$ ( $30 \mu \mathrm{g}$ of proteins) by pooling of the equal quantity ( $5 \mu \mathrm{g}$ of proteins) of the each individual sample from the patients A5-A10 (6 individuals). For one-dimensional (1-D) western blot, the samples were prepared in buffer containing $125 \mathrm{mM}$ Tris; $3.3 \%$ SDS; $10 \%$ glycerol and $5 \% 2$ mercaptoethanol (Sigma-Aldrich) and loaded on $13 \%$ SDS-PAGE gel in the following order: lane 1 sample 1a; lane 2 - sample 2a; lane 3 - sample 1b; and lane 4 - sample 2b. For two-dimensional (2-D) western blot, samples $1 \mathrm{a}$ and $2 \mathrm{a}$ (50 $\mu \mathrm{g}$ of proteins, prepared using the same procedure as for 1-D western blot) were loaded during rehydration of IPG strips (7 cm, IPG 3-10, Bio-Rad) in $125 \mu$ (total volume) of IEF buffer (7 M urea, $2 \mathrm{M}$ thiourea, $4 \%$ CHAPS, $10 \mathrm{mM}$ 1,4-dithioerythritol, $1.25 \%$ IPG buffer $\mathrm{pH}$ 3-10, Sigma-Aldrich) for $18 \mathrm{~h}$. Isoelectric focusing was carried out for a total $10 \mathrm{kVh}$ (50 $\mu \mathrm{A} / \mathrm{IPG}$ strip) using Multiphor II system (Pharmacia Biotech, Uppsala, Sweden). Prior to SDS-PAGE, IPG strips were equilibrated $15 \mathrm{~min}$ in solutions containing $6 \mathrm{M}$ urea, $0.375 \mathrm{M}$ Tris- $\mathrm{HCl}, \mathrm{pH} 8.8,2 \%$ SDS, $20 \%$ glycerol, $2 \%$ DTT and consequently in the same solution with $2.5 \%$ iodoacetamide instead of DTT. After equilibration, the IPG strips were applied on the top of $13 \%$ SDS-PAGE gels. SDS-PAGE was performed using Mini-Protean 3 Cell (Bio-Rad) at $15 \mathrm{~mA} / \mathrm{gel}$ for the first $15 \mathrm{~min}$ followed by $25 \mathrm{~mA} / \mathrm{gel}$ for the rest of separation. After SDS-PAGE the separated proteins were transferred onto polyvinylidene difluoride (PVDF) membrane Hybond-P (Amersham, GE Healthcare Life Sci, Uppsala, Sweden) at constant current $100 \mathrm{~V}$ for $1.5 \mathrm{~h}$ at $4{ }^{\circ} \mathrm{C}$. Membranes were probed with rabbit anti-VEGF antibody (Thermo Scientific, Pierce, Rockford, IL, USA) diluted 1:200 in blocking buffer and anti-rabbit IgG HRP-conjugated secondary antibody (dilution 1:2000, Dako Sweden AB, Stockholm, Sweden). The specific immunoreactivity was visualized using ECL detection kit (GE Healthcare, Uppsala, Sweden). Details for the analysis of NGF and TrkA levels are provided in the 
supplemental section since these proteins were not detected in tears of both aniridia patients and healthy subjects.

\section{Clinical examination of patients and in vivo confocal microscopy}

The cohort of aniridia patients and control subjects (if applicable, see Table 1) underwent full clinical bilateral corneal examination including data or tests as follows: gender, age, Schirmer's test, pachymetry of the central cornea, corneal sensitivity, and tear break-up time (BUT). Additional data consist of the status of PAX6 mutation (taken from patient records), and ethnicity. The techniques of the clinical tests were described in details previously [2]. Briefly, ultrasound pachymeter (TOMEY SP2000) was used to measure central corneal thickness. Tear production was assessed by Schirmer's test. Tear samples were excluded from analysis if the Schirmer's strip was moisten less than $10 \mathrm{~mm}$ in five minutes. Tear break-up time (BUT) was measured for evaluation the stability of tear film. BUT > $10 \mathrm{sec}$ (measured on the clear part of the cornea) was considered as normal. Corneal sensitivity was measured using Cochet-Bonnet esthesiometer (Luneau Ophthalmologie, France) with a nylon thread length of $60 \mathrm{~mm}$ considered as normal. The clinical data are summarized in Table 1. Moreover, a cornea-specific clinical in vivo confocal microscope (HRT3-RCM, Heidelberg Engineering, Heidelberg, Germany) was used to detect the presence of blood and lymph vessels in the patients corneas. The technique has been described in details previously [19]. Briefly, the $63 x$ immersion objective lens was placed in contact with the topically anesthetized cornea through a drop of optical coupling medium (carbomer $2 \mathrm{mg} / \mathrm{g}$; Viscotears ${ }^{\circledR}$ eye gel, THEA laboratories, France). The microscope field of view was aligned to the central or peripheral cornea, and depth was adjusted by a manual focusing ring. Laserscanned images were obtained in real time under software control, at various corneal locations and depths.

\section{Results}

The presented work provides comprehensive analysis of protein composition in the tears of patients with congenital aniridia and identifies differences in protein levels in patients' tears by comparing with 
healthy tears. Thus, two-dimensional map of tear proteome in aniridia has been established using IPG 3-10NL strips and 52 protein spots were analyzed and identified by LC-MS/MS (Fig. 1, Supplemental Table 1). To examine if protein composition and expression in tear fluid is specifically altered in aniridia patients, the 2-D protein patterns of tears in aniridia were compared with 2-D protein patterns obtained from normal tears using IPG 3-10NL strips and $13 \%$ polyacrylamide gels. Separated proteins were visualized by fluorescent SYPRO Ruby stain and detected using PDQuest 2-D analysis software. Image analysis of 34 gels derived from 34 eyes divided into patient group (18 eyes) and normal control group (16 eyes) revealed approximately 143 valid protein spots. All samples with clinical data are summarized in Table 1. Two tear samples from total of 20 patient samples were excluded from analysis due to remarkable different protein pattern observed (sample A4, see Table 1). Only spots present in all gels of the same group (valid spots) were analyzed. Using stringent criteria the image analysis revealed 7 protein spots with $P<0.01$ to be differently expressed in the tear fluid of aniridia patients compared with healthy individuals (Fig. 2, Table 2). Five of them were more abundant in healthy subjects, in particular $\alpha$-enolase $(P=0.0071)$, peroxiredoxin $6(P=0.0044)$, cystatin S $(P=0.0041)$, gelsolin $(P=0.0078)$, and apolipoprotein A-1 $(P=0.0073)$. Two other spots were more expressed in the tear fluid of aniridia patients and were identified as zinc- $\alpha 2$-glycoprotein $(P=0.00997)$ and lactoferrin $(P=0.0053)$. The complete list and nomenclature of all the proteins identified in 2-DE analysis, particularly the sequence coverage and the identified peptides is given in the Supplemental Table 1. The differentially expressed proteins were generally in weak correlation with the clinical parameters examined. Moderate correlation was found only in the case of peroxiredoxin 6, apolipoprotein A-1, $\alpha$-enolase, and cystatin S with disease duration and for peroxiredoxin 6 , $\alpha$-enolase, and cystatin S with corneal sensitivity. The Pearson correlation between proteomic data and clinical parameters is provided in Table 3.

Because the clinical examination of the patient cohort revealed abundant blood and lymph vessels with opaque corneas (Supplemental Fig. 3), as the next step we analyzed expression of potential vascularization factors, such as vascular endothelial growth factor (VEGF), nerve growth factor (NGF), and a soluble form of the high affinity nerve growth factor receptor TrkA in the samples from the same patient and control cohorts as were used in 2-DE analysis. For this aim, highly sensitive and specific western blot analyses were required since we were unable to detect and visualize these proteins using 2-DE based comparative proteomics combined with SYPRO Ruby 
staining and consequent LC-MS/MS identification due to their low abundance in tears as they function in very low levels in autocrine and/or paracrine mechanisms. One-dimensional immunoblot analysis revealed elevated VEGF levels in the patients tears. The immunoreactivity was present at the band of $\sim 80 \mathrm{kDa}$ (Fig. 3a, b), which is the molecular weight corresponding to c-form of VEGF (VEGF-C). Moreover, the analysis using 2-D western blot has not only confirmed the results from 1-D immunoblot but has also identified two VEGF isoforms, both with higher abundance in the patients' tears. However, the isoform with the isoelectric point about 7.4 was in much higher abundance in the patients' tears than in the controls. Further analysis is needed to identify posttranslational modification responsible for this effect. The expression levels of NGF and TrkA were not detected in tears of both aniridia patients and healthy subjects (data not shown).

\section{Discussion}

Analysis of protein profile in tear fluid is important for biomarker identification and potentially useful in the assessment of prognosis or treatment of ocular pathologies. The present study identifies, for the first time, proteins in the tear fluid from patients with congenital aniridia. Using 2-DE analysis and LCMS/MS we established 2-DE map of tear proteins in aniridia (Fig. 1, Supplemental Table 1) and identified proteins that were differently expressed in the tear fluid of patients when compared with the healthy tears. In order to obtain the most accurate results, no pooling of samples or sample fractionation and pre-enrichment protocols that may result in protein loss were used prior 2-DE analysis with the exception of the $3 \mathrm{kDa}$ cut-off filtration which was required for the sample desalting. Separate analysis of each individual sample has also the advantage of visual evaluation of protein patterns that show variation within the group. Thus, one patient (sample A4 from both eyes, see Table

1) was excluded from data analysis in this manner due to probable vascular leakage that was manifested by higher abundance of plasma proteins, such as serum albumin (Supplemental Fig. 1).

By comparing the global protein expression in tear fluid we found 7 protein spots with $P<$ 0.01 with different expression between patients and healthy subjects (Fig. 2, Table 2, and Supplemental Fig. 2). The expression of 5 proteins was greater in the healthy subjects; $\alpha$-enolase, 
peroxiredoxin 6, cystatin S, gelsolin, and apolipoprotein A-1.Two proteins, zink- $\alpha 2$-glycoprotein and lactoferrin, were found to be more expressed in aniridia patients. Additionally, due to defects in corneal innervation and pathological growth of blood and lymph vessels observed in the corneas of aniridia patients (Supplemental Fig. 3) we examined expression of VEGF, NGF, and soluble TrkA in the same patient and control cohorts using immunoblot analysis. Using the highly sensitive western blot analysis was required due to extremely low abundance of these proteins in the tear samples which prevented their detection in 2-DE gels with SYPRO Ruby stain and consequent LC-MS/MS identification. Using one- and two-dimensional western blot we have found greatly elevated VEGF levels in the tears of aniridia patients with the immunoreactivity present at the band of $\sim 80 \mathrm{kDa}$ which is the molecular mass corresponding to VEGF-C. VEGF-C is the member of VEGF family involved more specifically in the regulation of physiological and pathological growth of blood and lymphatic vessels [20]. Using 2-D immunodetection we confirmed the results obtained from 1-D western blot and, additionally, we were able to identify two VEGF isoforms with the similar molecular size of $\sim 80$ $\mathrm{kDa}$ present in higher levels in the patient tears. Moreover, one of these VEGF isoforms with isoelectric point $\mathrm{p} / \sim 7.4$ was even in much higher abundance in the patients than in the control tears. However, further investigation is needed to identify the process responsible for the observed posttranslational processing.

Additionally, we have also found that NGF, as another proangiogenic factor [21], and the soluble NGF receptor TrkA are probably not involved in the pathophysiology of aniridia since they were not detected in both patients and control tears (data not shown).

In the text below we discuss, in some details, the possible functional roles of the proteins with altered expression in the patient tears, identified in both approaches, in the context of aniridia pathophysiology.

$\alpha$-Enolase

$\alpha$-Enolase is a highly conserved enzyme catalyzing the conversion of 2-phosphoglycerate to phosphoenolpyruvate in the process of glycolysis. The levels of enolase isozymes may serve as a diagnostic tool for assessment of the severity and outcome of certain pathological conditions, e.g. stroke, cardiac arrest or other neurological disorders, as in the case of neuronal-specific enolase in 
plasma [22]. In regard of $\alpha$-enolase and its function in physiological or pathological conditions of eye, expression of this isozyme has been previously reported to be related to the limbal basal epithelium, as demonstrated by immunofluorescent microscopy [23]. In another study, an up-regulation of $\alpha$ enolase has been found in the tear fluid of patients with dry eye syndrome [24]. In the present study a-enolase was down-regulated (0.54-fold) suggesting that its down-regulation is not related with tear disturbances often found in this disease but more likely as a result of impaired corneal epithelial function caused by mutations in the PAX6 gene [25]. However, further studies are needed for evaluation of this finding and usefulness of this potential biomarker for development of symptomatic therapy for aniridia patients.

\section{Peroxiredoxin-6}

Another protein which may be involved in maintaining of corneal transparency is a glutationdependent peroxidase, peroxiredoxin 6 . It has been demonstrated that the topical administration of this protein had inhibitory effect on VEGF expression, inflammation, and suppressed neovascularization and apoptosis in ultraviolet irradiated rat corneas [26]. The presence of proteins involved in the metabolism of reactive oxygen species, such as peroxiredoxins and catalase in the normal tear film [27] suggests their function in the defense against these highly reactive and toxic compounds. Moreover, oxidative stress has been demonstrated to be a significant factor contributing to chronic wound state and wound-healing delay of corneas in Pax6+/- mouse model [28]. We have found that peroxiredoxin 6 was down-regulated $(0.69$-fold $)$ in the tears of aniridia patients when compared with healthy family members. Decreased expression of peroxiredoxin 6 may thus be associated to the elevated expression of VEGF in the tear fluid and to the increased corneal susceptibility to oxidative stress.

\section{Cystatin S and Lactoferrin}

Cystatins are naturally occurring inhibitors of cysteine proteinases. This function contributes to prevention of uncontrolled proteolysis and tissue damage [29-31]. The expression of these proteins in tears is also known to be reduced in several pathological conditions [32-35]. Cystatin S and lactoferrin are components of the corneal and the conjunctival epithelial defense against bacterial and viral pathogens. Lactoferrin is an iron-binding protein with bacteriostatic effect by impeding of iron 
utilization by bacteria [31]. In the present study we have found the levels of cystatin S decreased in aniridia tears $(0.54$-fold $)$. On the other hand, the levels of lactoferrin were increased (1.41-fold). It is tempting to hypothesize that the elevated expression of bacteriostatic lactoferrin in aniridia tears may be beneficial in corneal and conjunctival defense against pathogens compensating for a cystatin insufficiency.

\section{Gelsolin}

The gelsolin family of proteins is involved in cytoskeletal rearrangement controlling actin organization by binding, severing and capping of actin filaments [36]. In addition to their role in actin filament remodeling, these proteins play roles in many cellular processes, such as cell motility, apoptosis or regulation of gene expression [37]. The levels of gelsolin have been found to be up-regulated in the corneal epithelium of patients with keratoconus [38]. In the present study we found a decreased expression of gelsolin in tears from aniridia patients $(0.69$-fold). The decreased expression of this protein may contribute to the many defects attributed to the corneal epithelium in aniridia.

\section{Zinc- $\alpha 2-g l y c o p r o t e i n$}

Zinc- $\alpha 2-$ glycoprotein (ZAG) is a $41 \mathrm{kDa}$ protein which is secreted in various body fluids, such as plasma, saliva and tears with multifunctional roles including stimulation of lipid breakdown in adipocytes, and expression of immune response or insulin resistance [39;40]. The altered abundance of this protein in tears was found in several pathological eye conditions. For example, increased abundance of ZAG was found in the tears of keratoconus patients [15], in patients with Grave's ophthalmopathy [41] or keratitis [42]. On the other hand, no significant changes of this protein were noticed in tears from patients with dry eye syndrome [43]. In the present study we have found elevated levels of ZAG in aniridia tears (1.4-fold). The exact role of up-regulated ZAG in aniridia is unknown but the alterations in the tear lipidome profile observed in patients with fungal keratitis [42] may suggest its possible role in the tear lipid degradation. The tear film break-up time in aniridic patients is often short [44] and here ZAG may play a role in changes the qualities of the lipid layer in the tear film.

\section{Apolipoprotein A-1}


Apolipoproteins are lipid-binding proteins which transport the lipids through the lymphatic and blood circulatory systems. Besides their lipid-transporting function, an anti-inflammatory effect of apolipoproteins has also been demonstrated [45;46]. Increased secretion of apolipoprotein A-I by lacrimal gland was reported in patients with advanced diabetic retinopathy [47] as well as in tears of patients with fungal keratitis [42]. In the present study, we have found a decreased content of apolipoprotein A-1 in the tear fluid of patients with aniridia (0.53-fold) contributing to an insufficiency in the anti-inflammatory potential of tear film in patients with aniridia. This may be one possible explanation for the elevated numbers of dendritic immune cells in the central cornea, even in the absence of evident signs of inflammation, suggesting on a subclinical form of inflammation in earlystage of aniridia associated keratopathy [2].

\section{Vascular endothelial growth factor (VEGF)}

Pathological corneal vascularization or aniridia associated keratopathy is an associated ocular abnormality in aniridia patients (Fig. 3). Corneal avascularity, which is a prerequisite for intact vision, is achieved by maintaining of low corneal levels of VEGF expression and strong expression of vascular endothelial growth factor receptor 3 (VEGFR-3) by corneal epithelium [48]. Up-regulation of both VEGF-C and VEGFR-3 has also been demonstrated in inflamed rat corneas [49]. In the present study we found greatly elevated expression of VEGF in the tear fluid of aniridia patients identified as the immunoreactive band of $\sim 80 \mathrm{kDa}$, which is the molecular size corresponding to VEGF-C (Fig. 3a, b), suggesting a breakdown of balance between pro- and anti-angiogenic factors and stimulation of angiogenesis and lymphangiogenesis. Moreover, analysis of VEGF expression by two-dimensional western blot revealed that posttranslational processing of this protein may play a significant role in regulation involved in aniridia pathophysiology since we found highly up-regulated isoform with $\mathrm{p} /$ around 7.4 in the patient tears (Fig. 3b).

\section{Conclusion}

The proteomic analysis of tears in patients with aniridia has identified proteins with significant differences in abundance when compared to healthy tears. Five proteins were down-regulated: $\alpha$ - 
enolase, peroxiredoxin 6, cystatin S, gelsolin, and apolipoprotein A-1. Two proteins were upregulated: zinc- $\alpha 2$-glycoprotein and lactoferrin. Likewise $80 \mathrm{kDa}$ VEGF isoform corresponding to VEGF-C was found up-regulated using 1- and 2-dimensional western blot. NGF and the receptor TrkA were not detected. Further studies are needed to clarify the involvement of the identified proteins in aniridia pathophysiology and their potential as targets for the symptomatic therapy of this severe ocular condition.

\section{Acknowledgement}

We thank aniridia patients, their families, and healthy volunteers for their valuable cooperation in this study.

\section{Competing interests}

The authors declare that they have no competing interests. All authors read and approved the final manuscript. 
References

[1] Lee H, Khan R, O'Keefe M. Aniridia: current pathology and management. Acta Ophthalmol 2008;86(7):708-15.

[2] Edén U, Fagerholm P, Danyali R, Lagali N. Pathologic epithelial and anterior corneal nerve morphology in early-stage congenital aniridic keratopathy. Ophthalmology 2012;119(9):180310.

[3] Nubile M, Lanzini M, Miri A, Pocobelli A, Calienno R, Curcio C, et al. In vivo confocal microscopy in diagnosis of limbal stem cell deficiency. Am J Ophthalmol 2013;155(2):220-32.

[4] Secker GA, Daniels JT. Corneal epithelial stem cells: deficiency and regulation. Stem Cell Rev 2008;4(3):159-68.

[5] Li W, Hayashida Y, Chen YT, Tseng SC. Niche regulation of corneal epithelial stem cells at the limbus. Cell Res 2007;17(1):26-36.

[6] Dua HS, Joseph A, Shanmuganathan VA, Jones RE. Stem cell differentiation and the effects of deficiency. Eye 2003;17(8):877-85.

[7] Mayer KL, Nordlund ML, Schwartz GS, Holland EJ. Keratopathy in congenital aniridia. Ocul Surf $2003 ; 1(2): 74-9$.

[8] Edén U. On aniridia in Sweden and Norway. PhD thesis.Lund University, Department of Clinical Sciences, Ophthalmology, Faculty of Medicine. 2009.

[9] Ambati BK, Nozaki M, Singh N, Takeda A, Jani PD, Suthar T, et al. Corneal avascularity is due to soluble VEGF receptor-1. Nature 2006;443(7114):993-7.

[10] Li Z, Burns AR, Han L, Rumbaut RE, Smith CW. IL-17 and VEGF are necessary for efficient corneal nerve regeneration. Am J Pathol 2011;178(3):1106-16.

[11] Yu CQ, Zhang M, Matis KI, Kim C, Rosenblatt MI. Vascular endothelial growth factor mediates corneal nerve repair. Invest Ophthalmol Vis Sci 2008;49(9):3870-8.

[12] Leiper LJ, Ou J, Walczysko P, Kucerova R, Lavery DN, West JD, et al. Control of patterns of corneal innervation by Pax6. Invest Ophthalmol Vis Sci 2009;50(3):1122-8.

[13] Qi H, Li DQ, Shine HD, Chen Z, Yoon KC, Jones DB, et al. Nerve growth factor and its receptor TrkA serve as potential markers for human corneal epithelial progenitor cells. Exp Eye Res 2008;86(1):34-40.

[14] Saijyothi AV, Angayarkanni N, Syama C, Utpal T, Shweta A, Bhaskar S, et al. Two dimensional electrophoretic analysis of human tears: Collection method in dry eye syndrome.

Electrophoresis 2010;31(20):3420-7.

[15] Lema I, Brea D, Rodriguez-Gonzalez R, Diez-Feijoo E, Sobrino T. Proteomic analysis of the tear film in patients with keratoconus. Mol Vis 2010;16:2055-61.:2055-61.

[16] Kramann C, Boehm N, Lorenz K, Wehrwein N, Stoffelns B, Pfeiffer N, et al. Effect of contact lenses on the protein composition in tear film: a ProteinChip study. Graef Arch Clin Exp 2010;111.

[17] Green-Church KB, Nichols KK, Kleinholz NM, Zhang L, Nichols JJ. Investigation of the human tear film proteome using multiple proteomic approaches. Mol Vis 2008;14:456-70.:456-70. 
[18] Theodorsson E. BASIC computer program to summarize data using nonparametric and parametric statistics including Anderson-Darling test for normality. Comput Prog Biomed 1988;26(2):207-13.

[19] Peebo BB, Fagerholm P, Lagali N. In vivo confocal microscopy visualization of presumed lymph vessels in a case of corneal transplant rejection. Clin Exp Ophthalmol 2011;39(8):832-4.

[20] Cao Y, Linden P, Farnebo J, Cao R, Eriksson A, Kumar V, et al. Vascular endothelial growth factor $C$ induces angiogenesis in vivo. PNAS 1998;95(24):14389-94.

[21] Seo K, Choi J, Park M, Rhee C. Angiogenesis effects of nerve growth factor (NGF) on rat corneas. J Vet Sci 2001;2(2):125-30.

[22] Schoerkhuber W, Kittler H, Sterz F, Behringer W, Holzer M, Frossard M, et al. Time Course of Serum Neuron-Specific Enolase: A Predictor of Neurological Outcome in Patients Resuscitated From Cardiac Arrest. Stroke 1999;30(8):1598-603.

[23] Zieske JD, Bukusoglu G, Yankauckas MA, Wasson ME, Keutmann HT. $\alpha$-Enolase is restricted to basal cells of stratified squamous epithelium. Dev Biol 1992;151(1):18-26.

[24] Zhou L, Beuerman RW, Chan CM, Zhao SZ, Li XR, Yang H, et al. Identification of tear fluid biomarkers in dry eye syndrome using ITRAQ quantitative proteomics. J Proteome Res 2009;8(11):4889-905.

[25] Collinson JM, Chanas SA, Hill RE, West JD. Corneal development, limbal stem cell function, and corneal epithelial cell migration in the Pax6(+/-) mouse. Invest Ophth Vis Sci 2004;45(4):1101-8.

[26] Shi H, Yu HJ, Wang HY, Wang WT, Jin SH, Zhu P, et al. Topical administration of peroxiredoxin- 6 on the cornea suppresses inflammation and neovascularization induced by ultraviolet radiation. Invest Ophth Vis Sci 2012;53(13):8016-28.

[27] de Souza GA, Godoy LM, Mann M. Identification of 491 proteins in the tear fluid proteome reveals a large number of proteases and protease inhibitors. Genome Biol 2006;7(8):R72.

[28] Ou J, Walczysko P, Kucerova R, Rajnicek AM, McCaig CD, Zhao M, et al. Chronic wound state exacerbated by oxidative stress in Pax6+/- aniridia-related keratopathy. J Pathol 2008;215(4):421-30.

[29] Abrahamson M, Alvarez-Fernandez M, Nathanson CM. Cystatins. Biochem Soc Symp 2003;(70):179-99.

[30] Barka T, Asbell PA, van der Noen H, Prasad A. Cystatins in human tear fluid. Curr Eye Res 1991;10(1):25-34.

[31] Gachon AM, Lacazette E. Tear lipocalin and the eye's front line of defence. Br J Ophthalmol 1998;82(4):453-5.

[32] ter Rahe BS, van Haeringen NJ. Cystatins in tears of patients with different corneal conditions. Ophthalmologica 1998;212(1):34-6.

[33] Anderson JA, Leopold IH. Antiproteolytic activities found in human tears. Ophthalmology $1981 ; 88(1): 82-4$.

[34] Koo BS, Lee DY, Ha HS, Kim JC, Kim CW. Comparative analysis of the tear protein expression in blepharitis patients using two-dimensional electrophoresis. J Proteome Res 2005;4(3):71924. 
[35] Acera A, Vecino E, Rodriguez-Agirretxe I, Aloria K, Arizmendi JM, Morales C, et al. Changes in tear protein profile in keratoconus disease. Eye 2011;25(9):1225-33.

[36] Sun HQ, Yamamoto M, Mejillano M, Yin HL. Gelsolin, a multifunctional actin regulatory protein. J Biol Chem 1999;274(47):33179-82.

[37] Silacci P, Mazzolai L, Gauci C, Stergiopulos N, Yin HL, Hayoz D. Gelsolin superfamily proteins: key regulators of cellular functions. Cell Mol Life Sci 2004;61(19-20):2614-23.

[38] Nielsen K, Vorum H, Fagerholm P, Birkenkamp-Demtroder K, Honore B, Ehlers N, et al. Proteome profiling of corneal epithelium and identification of marker proteins for keratoconus, a pilot study. Exp Eye Res 2006;82(2):201-9.

[39] Hassan M, Waheed A, Yadav S, Singh TP, Ahmad F. Zinc a2-glycoprotein: a multidisciplinary protein. Mol Cancer Res 2008;6(6):892-906.

[40] Yang M, Liu R, Li S, Luo Y, Zhang Y, Zhang L, et al. Zinc- $\alpha 2$-glycoprotein is associated with insulin resistance in humans and is regulated by hyperglycemia, hyperinsulinemia, or liraglutide administration: Cross-sectional and interventional studies in normal subjects, insulin-resistant subjects, and subjects with newly diagnosed diabetes. Diabetes Care 2012.

[41] Baker GR, Morton M, Rajapaska RS, Bullock M, Gullu S, Mazzi B, et al. Altered tear composition in smokers and patients with graves ophthalmopathy. Arch Ophthalmol 2006;124(10):1451-6.

[42] Ananthi S, Venkatesh PN, Lalitha P, Valarnila M, Dharmalingam K. Pathogen induced changes in the protein profile of human tears from Fusarium keratitis patients. PLoS ONE 2013;8(1):e53018.

[43] Versura P, Nanni P, Bavelloni A, Blalock WL, Piazzi M, Roda A, et al. Tear proteomics in evaporative dry eye disease. Eye 2010.

[44] De La Paz MF, Blanco Z, Alvarez J. Ocular surface findings in patients with congential aniridia. Acta Ophthalmol 2009;87:0.

[45] Patel S, Di Bartolo BA, Nakhla S, Heather AK, Mitchell TW, Jessup W, et al. Anti-inflammatory effects of apolipoprotein A-I in the rabbit. Atherosclerosis 2010;212(2):392-7.

[46] Murphy AJ, Hoang A, Aprico A, Sviridov D, Chin-Dusting J. Anti-inflammatory functions of apolipoprotein A-I and high-density lipoprotein are preserved in trimeric apolipoprotein A-I. J Pharmacol Exp Ther 2013;344(1):41-9.

[47] Kawai S, Nakajima T, Hokari S, Komoda T, Kawai K. Apolipoprotein A-I concentration in tears in diabetic retinopathy. Ann Clin Biochem 2002;39(1):56-61.

[48] Cursiefen C, Chen L, Saint-Geniez M, Hamrah P, Jin Y, Rashid S, et al. Nonvascular VEGF receptor 3 expression by corneal epithelium maintains avascularity and vision. PNAS 2006;103(30):11405-10.

[49] Mimura T, Amano S, Usui T, Kaji Y, Oshika T, Ishii Y. Expression of vascular endothelial growth factor $C$ and vascular endothelial growth factor receptor 3 in corneal lymphangiogenesis. Exp Eye Res 2001;72(1):71-8. 
Figure legends

Fig. 1

2-D protein reference map of tear film in aniridia. The protein spots which were identified by LCMS/MS are numbered and the differentially expressed spots with $P<0.01$ are labelled in red (see Table 2 and Suppl. Table 1 for more details).

Fig. 2

A. Proteins differentially expressed in the tear fluid between aniridia patients and healthy controls with $P<0.01$. Each bar represents the mean of the relative spot volume intensity \pm SEM.

B. Microphotographs of the proteins differentially expressed in the tears from patients with aniridia vs. normal tears.

Fig. 3

Increased levels of VEGF in the tear fluid from patients with aniridia.

A. One-dimensional western blot analysis of VEGF in aniridic and healthy tears. Lane 1 and lane 3: control sample 1a and control sample $1 \mathrm{~b}$ respectively; lane 2 and lane 4: patient sample 2a and patient sample $2 b$ respectively.

B. Two-dimensional western blot analysis of VEGF in patient and healthy tears. Tear samples used for 2-D western blot were as follows: Controls: sample 1a; Patients: sample 2a. (see Material and methods for more details) 




Figure 1 
A.



B.

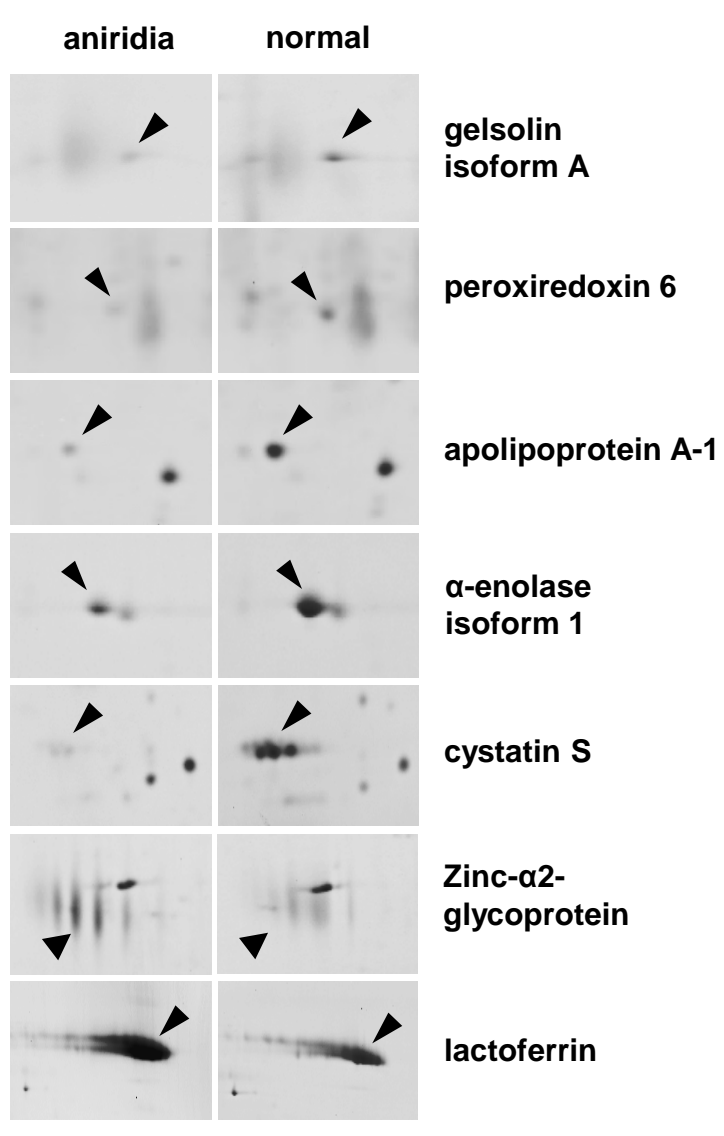


A.

$\begin{array}{llll}1 & 2 & 3 & 4\end{array}$

80 kDa -

B.

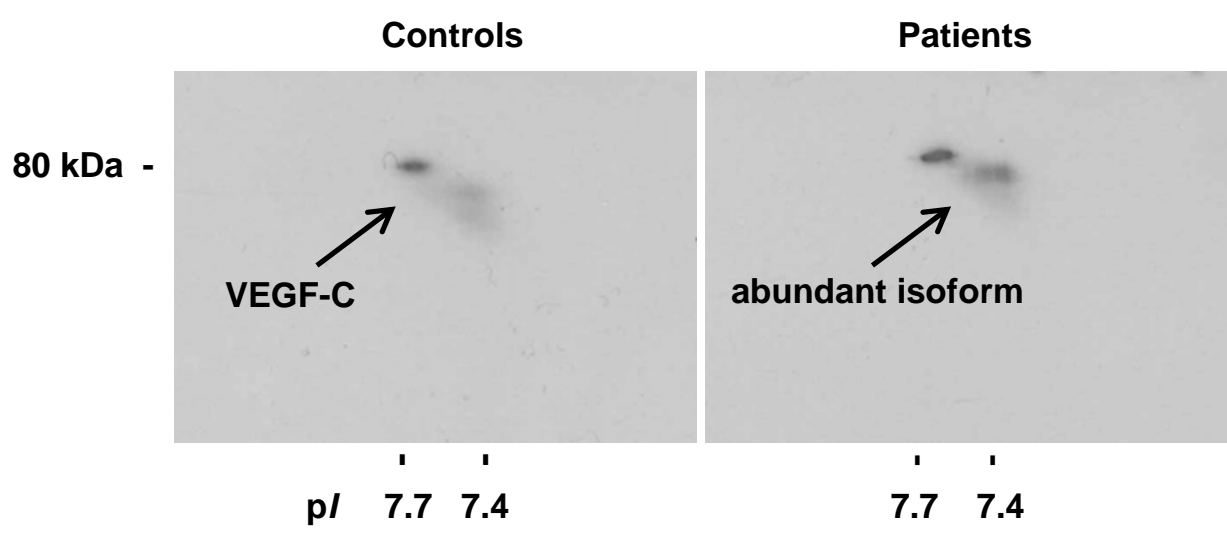

Figure 3. 
Table 1 List of analyzed patient and control samples with clinical data

\begin{tabular}{|c|c|c|c|c|c|c|c|c|c|c|c|}
\hline \multirow{2}{*}{$\begin{array}{c}\text { Sample } \\
\text { ID }\end{array}$} & \multirow[t]{2}{*}{ Gender } & \multirow[t]{2}{*}{ Age } & \multicolumn{2}{|c|}{ Shirmer test } & \multicolumn{2}{|c|}{ Pachymetry } & \multicolumn{2}{|c|}{ Corneal sensitivity } & \multicolumn{2}{|c|}{ BUT } & \multirow[t]{2}{*}{ Note } \\
\hline & & & $\mathrm{R}$ & $\mathrm{L}$ & $\mathrm{R}$ & $\mathrm{L}$ & $\mathrm{R}$ & $\mathrm{L}$ & $\mathrm{R}$ & $\mathrm{L}$ & \\
\hline $\mathrm{A} 1$ & $\mathrm{~F}$ & 17 & 26 & 35 & 641 & 657 & 50 & 50 & 6 & 8 & $1, a, b, c, n$ \\
\hline $\mathrm{A} 2$ & $M$ & 55 & 35 & 35 & 663 & 677 & 35 & 20 & 9 & 9 & $1, a, b, c, n$ \\
\hline $\mathrm{A} 3$ & $\mathrm{~F}$ & 21 & 35 & 35 & 602 & 608 & 60 & 60 & 9 & 16 & $1, a, b, c, n$ \\
\hline A4 & $\mathrm{F}$ & 30 & 10 & 12 & 646 & 701 & 35 & 35 & 0 & 0 & $1, a, b, c, n$ \\
\hline A5 & M & 33 & 29 & 35 & 587 & 580 & 60 & 60 & 5 & 5 & $1, a, b, c, n$ \\
\hline $\mathrm{A} 6$ & $\mathrm{~F}$ & 36 & 20 & 35 & 660 & 667 & 10 & 20 & 9 & 9 & $1, a, b, c, n$ \\
\hline A7 & $M$ & 34 & 30 & 35 & 599 & 604 & 35 & 50 & 5 & 15 & $1, a, b, c, n$ \\
\hline A8 & M & 21 & 25 & 28 & 683 & 642 & 50 & 60 & 11 & 11 & $1, \mathrm{a}, \mathrm{b}, \mathrm{c}, \mathrm{n}$ \\
\hline A9 & $\mathrm{F}$ & 20 & 30 & 35 & 671 & 649 & 60 & 60 & 5 & 15 & $1, \mathrm{a}, \mathrm{b}, \mathrm{c}, \mathrm{n}$ \\
\hline A10 & $M$ & 19 & 35 & 30 & 1135 & 622 & 25 & 45 & 9 & 10 & $1, a, b, c, n$ \\
\hline C1 & $F$ & 55 & 35 & 35 & 554 & 554 & 60 & 60 & 11 & 11 & $2, a, n$ \\
\hline $\mathrm{C} 2$ & $M$ & 56 & 11 & 16 & 526 & 526 & 60 & 60 & 15 & 16 & $2, a, n$ \\
\hline $\mathrm{C} 3$ & $\mathrm{~F}$ & 26 & 30 & 35 & 597 & 597 & 60 & 60 & 11 & 14 & $2, a, n$ \\
\hline $\mathrm{C} 4$ & $\mathrm{~F}$ & 49 & 25 & 17 & 497 & 497 & 60 & 60 & 13 & 14 & $2, a, n$ \\
\hline C5 & $\mathrm{F}$ & 24 & 27 & 17 & $\mathrm{~N} / \mathrm{A}$ & $\mathrm{N} / \mathrm{A}$ & 60 & 60 & 14 & 13 & $2, a, n$ \\
\hline C6 & $M$ & 35 & 31 & 31 & $\mathrm{~N} / \mathrm{A}$ & $\mathrm{N} / \mathrm{A}$ & $\mathrm{N} / \mathrm{A}$ & $\mathrm{N} / \mathrm{A}$ & $\mathrm{N} / \mathrm{A}$ & $\mathrm{N} / \mathrm{A}$ & $3, a, n$ \\
\hline $\mathrm{C} 7$ & $M$ & 41 & 11 & 10 & $\mathrm{~N} / \mathrm{A}$ & $\mathrm{N} / \mathrm{A}$ & $\mathrm{N} / \mathrm{A}$ & N/A & N/A & $\mathrm{N} / \mathrm{A}$ & $3, a, n$ \\
\hline C8 & $\mathrm{F}$ & 31 & 29 & 34 & $\mathrm{~N} / \mathrm{A}$ & $\mathrm{N} / \mathrm{A}$ & $\mathrm{N} / \mathrm{A}$ & $\mathrm{N} / \mathrm{A}$ & $\mathrm{N} / \mathrm{A}$ & $\mathrm{N} / \mathrm{A}$ & $3, a, n$ \\
\hline
\end{tabular}

Abbreviations: $\mathrm{A} 1-\mathrm{A} 10$ = patients; $\mathrm{C} 1-\mathrm{C} 8$ = controls; F/M - female/male; $\mathrm{R}$ - right eye; $\mathrm{L}$ - left eye; N/A not applicable; BUT - tear breakup time

Notes: 1 - patient; 2 - healthy relatives with the same genetic background but without PAX6 mutation; 3 volunteers; $a$ - ethnicity: Caucasian; $b$ - disease duration is the same as the age of each of the patient due to inherited feature of congenital aniridia; $\mathrm{c}$ - confirmed PAX6 mutation; $\mathrm{n}$ - no therapy 
Table 2 Summary of differentially expressed tear proteins in aniridia identified by 2-DE

\begin{tabular}{|c|c|c|c|c|c|c|c|c|c|c|}
\hline \multirow[b]{2}{*}{$\begin{array}{l}\text { Spot } \\
\text { nr. }\end{array}$} & \multirow[b]{2}{*}{ Protein name } & \multirow[b]{2}{*}{$\begin{array}{l}\text { Database nr. } \\
\text { NCBI }\end{array}$} & \multirow[b]{2}{*}{$\begin{array}{l}\text { Theor. } \\
M r\end{array}$} & \multirow[b]{2}{*}{$\begin{array}{l}\text { Theor. } \\
\text { pl }\end{array}$} & \multirow[b]{2}{*}{$\begin{array}{l}\text { MASCOT } \\
\text { score } \\
\text { (MS) }\end{array}$} & \multirow[b]{2}{*}{$\begin{array}{l}\text { Matches/ } \\
\text { Sequence } \\
\text { coverage }\end{array}$} & \multicolumn{2}{|c|}{$\begin{array}{l}\text { Protein abundance } \\
\quad(\text { mean } A U)\end{array}$} & \multirow{2}{*}{$\begin{array}{l}\begin{array}{l}\text { Fold } \\
\text { change }\end{array} \\
\text { healthy } \\
\text { vs. } \\
\text { aniridia } \\
\text { tears }\end{array}$} & \multirow{2}{*}{$\begin{array}{l}P \text { - value } \\
\text { healthy } \\
\text { vs. } \\
\text { aniridia } \\
\text { tears }\end{array}$} \\
\hline & & & & & & & $\begin{array}{l}\text { aniridia } \\
\text { tears } \\
(n=18)\end{array}$ & $\begin{array}{l}\text { healthy } \\
\text { tears } \\
(n=16)\end{array}$ & & \\
\hline 5904 & gelsolin isoform A & gi|4504165 & 86043 & 5.9 & 449 & $8(6) / 12 \%$ & 148.41 & 214.28 & 0.7 & 0.0078 \\
\hline 6205 & peroxiredoxin 6 & gi|4758638 & 25133 & 6.0 & 463 & $12(5) / 55 \%$ & 519.58 & 754.84 & 0.7 & 0.0044 \\
\hline 2208 & $\begin{array}{l}\text { apolipoprotein A-1 } \\
\text { precursor }\end{array}$ & gi|4557321 & 30759 & 5.56 & 707 & $17(5) / 44 \%$ & 778.77 & 1478.08 & 0.5 & 0.0073 \\
\hline 7510 & $\begin{array}{l}\text { alpha-enolase, } \\
\text { isoform } 1\end{array}$ & gi|4503571 & 47481 & 7.01 & 641 & $10(9) / 28 \%$ & 1030.93 & 1902.97 & 0.5 & 0.0071 \\
\hline 0007 & $\begin{array}{l}\text { cystatin S } \\
\text { precursor }\end{array}$ & gi|4503109 & 16489 & 4.95 & 268 & $6(3) / 25 \%$ & 1506.45 & 2811.34 & 0.5 & 0.0041 \\
\hline 2302 & $\begin{array}{l}\text { Zn-alpha2- } \\
\text { glycoprotein }\end{array}$ & gi|38026 & 34942 & 5.71 & 542 & $16(7) / 38 \%$ & 23349.83 & 16687.19 & 1.4 & 0.0100 \\
\hline 8801 & lactoferrin & gi|186833 & 80228 & 8.56 & 2249 & $54(38) / 53 \%$ & 68084.26 & 48241.02 & 1.4 & 0.0053 \\
\hline
\end{tabular}

Abbreviations: $\mathrm{AU}=$ arbitrary units, Theor. $\mathrm{Mr}=$ theoretical molecular weight, Theor. $\mathrm{p} /=$ theoretical isoelectric point. 
Table 3 Correlation analysis of proteomic data with the clinical parameters for the patient group

\begin{tabular}{|c|c|c|c|c|c|c|}
\hline \multicolumn{7}{|c|}{ Pearson's correlation } \\
\hline $\begin{array}{l}\text { Spot } \\
\text { nr. }\end{array}$ & Protein name & $\begin{array}{l}\text { Disease } \\
\text { duration }\end{array}$ & $\begin{array}{l}\text { Schirmer } \\
\text { test }\end{array}$ & Pachymetry & $\begin{array}{l}\text { Corneal } \\
\text { sensitivity }\end{array}$ & BUT \\
\hline 5904 & $\begin{array}{l}\text { gelsolin } \\
\text { isoform A }\end{array}$ & 0.1320 & 0.1134 & -0.1972 & -0.0838 & -0.1934 \\
\hline 6205 & peroxiredoxin 6 & 0.4280 & 0.2978 & 0.1630 & -0.3773 & -0.0402 \\
\hline 2208 & $\begin{array}{l}\text { apolipoprotein A-1 } \\
\text { precursor }\end{array}$ & 0.3659 & 0.1226 & -0.1170 & -0.1840 & -0.2441 \\
\hline 7510 & $\begin{array}{l}\text { alpha-enolase, } \\
\text { isoform } 1\end{array}$ & 0.3441 & 0.2712 & -0.0228 & -0.3314 & -0.0499 \\
\hline 0007 & $\begin{array}{l}\text { cystatin S } \\
\text { precursor }\end{array}$ & -0.5479 & -0.1360 & 0.0875 & 0.3178 & 0.2143 \\
\hline 2302 & $\begin{array}{l}\text { Zn-alpha2- } \\
\text { glycoprotein }\end{array}$ & 0.1466 & -0.2072 & 0.0815 & -0.1535 & -0.1610 \\
\hline 8801 & lactoferrin & 0.1449 & 0.0346 & -0.3781 & 0.1044 & -0.1065 \\
\hline
\end{tabular}


Immunoprecipitation and western blot analysis of NGF and soluble TrkA in aniridic and healthy tears

Immunoprecipitation (IP) method was used for detection of NGF and soluble form of the high affinity NGF receptor TrkA. Two samples (200 $\mu \mathrm{g}$ of total protein) were prepared by pooling of an appropriate volume of individual samples from all samples of the patients group (samples A1-A10 excepting of sample A4) or from all samples from the control group (samples C1-C8). Samples prepared in buffer containing $20 \mathrm{mM}$ Tris, $7 \mathrm{M}$ urea, $2 \mathrm{M}$ thiourea, 0.1 \% CHAPS, $10 \mathrm{mM}$ 1,4-dithioerythritol (Sigma-Aldrich Sweden AB, Stockholm, Sweden), 0.5\% ampholytes 3-10 (Bio-Rad Laboratories, Hercules, CA, USA), and protease inhibitor cocktail (Complete mini, Roche Diagnostics Scandinavia AB, Stockholm, Sweden) were diluted in $50 \mathrm{mM}$ Tris- $\mathrm{HCl}, \mathrm{pH} 7.5$ in order to decrease the concentration of denaturing agents that can disturb IP reaction. After centrifugation $\left(14,000 \times \mathrm{g}, 15 \mathrm{~min}, 4^{\circ} \mathrm{C}\right)$, the supernatants were incubated with NGF or TrkA antibody $(4 \mu \mathrm{g})$ for $1 \mathrm{~h}$ at $4^{\circ} \mathrm{C}$ with gentle shaking followed by incubation with $40 \mu$ of Protein $\mathrm{G}$ sepharose beads (GE Healthcare Life Sci, Uppsala, Sweden) for $1 \mathrm{~h}$ at $4{ }^{\circ} \mathrm{C}$ on orbital shaker. After centrifugation ( $5000 \times \mathrm{g}, 1 \mathrm{~min}, 4^{\circ} \mathrm{C}$ ), the beads with immunocomplex were washed 3 times with $1 \mathrm{ml}$ buffer containing $25 \mathrm{mM}$ Tris- $\mathrm{HCl}, \mathrm{pH}$ 7.5, $140 \mathrm{mM} \mathrm{NaCl}, 1$ \% NP-40, 1 \% sodium deoxycholate, and 0.1 \% sodium dodecyl sulphate (SDS). The last wash was performed with $50 \mathrm{mM}$ Tris- $\mathrm{HCl}, \mathrm{pH} 7.5$ and the samples were prepared for SDS-PAGE by incubating of beads in reduction buffer containing $125 \mathrm{mM}$ Tris- $\mathrm{HCl}, \mathrm{pH} 6.8 ; 3.3 \%$ SDS, $10 \%$ glycerol, $5 \%$ 2-mercaptoethanol for 5 min at $95{ }^{\circ} \mathrm{C}$. Immunoprecipitated proteins were separated on polyacrylamide gels (18\% for NGF and $8 \%$ for TrkA), transferred onto PVDF membrane and incubated with the specific antibodies, rabbit anti-NGF (1:1000, Cell Signaling, Danvers, MA, USA) or rabbit anti-TrkA (extracellular domain; 1:1000, antibodies-online $\mathrm{GmbH}$, Aachen, Germany) for NGF or TrkA detection respectively. Consequently, the membranes were incubated with anti-rabbit IgG HRP-conjugated secondary antibody diluted 1:2000 in blocking buffer (Dako Sweden AB, Stockholm, Sweden) followed by ECL detection 
Suppl. Table 1 Summary table from MASCOT identification for all the identified proteins in the tear fluid of aniridia patients using 2-DE based proteomics.

\begin{tabular}{|c|c|c|c|c|c|c|c|c|}
\hline $\begin{array}{l}\text { Spot } \\
\text { no. }\end{array}$ & Protein name & Database nr. (NCBI) & $\begin{array}{l}\text { Theor. } \\
M r\end{array}$ & $\begin{array}{l}\text { Theor. } \\
\text { pl }\end{array}$ & $\begin{array}{l}\text { Matches/ } \\
\text { Sequence } \\
\text { coverage }\end{array}$ & $\begin{array}{l}\text { MASCOT } \\
\text { score } \\
\text { MS }\end{array}$ & $\begin{array}{l}\text { MASCOT } \\
\text { score } \\
\text { MS/MS }\end{array}$ & MASCOT peptides identified by MS/MS \\
\hline 0007 & $\begin{array}{l}\text { cystatin-S } \\
\text { precursor }\end{array}$ & NCBI/gi|4503109 & 16489 & 4.95 & $\begin{array}{l}6(3) \\
25 \%\end{array}$ & 168 & $\begin{array}{l}22 \\
29 \\
20 \\
119 \\
117 \\
84\end{array}$ & $\begin{array}{l}\text { ALHFAISEYNK } \\
\text { ALHFAISEYNK } \\
\text { ATEDEYYR } \\
\text { EQTFGGVNYFFDVEVGR } \\
\text { EQTFGGVNYFFDVEVGR } \\
\text { EQTFGGVNYFFDVEVGR }\end{array}$ \\
\hline 0107 & $\begin{array}{l}\text { prolactin-inducible protein } \\
\text { precursor }\end{array}$ & NCBI/ gi|4505821 & 16847 & 8.26 & $\begin{array}{l}11(6) / \\
60 \%\end{array}$ & 469 & $\begin{array}{l}21 \\
86 \\
87 \\
60 \\
35 \\
23 \\
101 \\
62 \\
17 \\
39 \\
64\end{array}$ & $\begin{array}{l}\text { NFDIPK } \\
\text { SVRPNDEVTAVLAVQTELK } \\
\text { SVRPNDEVTAVLAVQTELK } \\
\text { TYLISSIPLQGAFNYK } \\
\text { YTACLCDDNPK } \\
\text { TVQIAAVVDVIR } \\
\text { TVQIAAVVDVIR } \\
\text { ELGICPDDAAVIPIK } \\
\text { FYTIEILK } \\
\text { FYTIEILK } \\
\text { FYTIEILKVE }\end{array}$ \\
\hline 0225 & immunoglobulin J chain & NCBI/ gi|114319027 & 20046 & 5.27 & $\begin{array}{l}6(4) / \\
21 \%\end{array}$ & 181 & $\begin{array}{l}29 \\
93 \\
48 \\
71 \\
11 \\
49\end{array}$ & $\begin{array}{l}\text { IVLVDNK } \\
\text { SSEDPNEDIVER } \\
\text { SSEDPNEDIVER } \\
\text { SSEDPNEDIVER } \\
\text { IIVPLNNR } \\
\text { FVYHLSDLCK }\end{array}$ \\
\hline 1003 & cystatin S & NCBI/ gi|4503109 & 16489 & 4.74 & $3(1) /$ & 165 & 34 & ALHFAISEYNK \\
\hline
\end{tabular}


precursor

$19 \%$

131 EQTFGGVNYFFDVEVGR

40 EQTFGGVNYFFDVEVGR

\begin{tabular}{|c|c|c|c|c|c|c|c|c|}
\hline \multirow[t]{10}{*}{1301} & prolactin-inducible protein & NCBI/ gi|4505821 & 16847 & 8.26 & $10(7) /$ & 419 & 18 & NFDIPK \\
\hline & precursor & & & & $53 \%$ & & 55 & SVRPNDEVTAVLAVQTELK \\
\hline & & & & & & & 98 & SVRPNDEVTAVLAVQTELK \\
\hline & & & & & & & 55 & TYLISSIPLQGAFNYK \\
\hline & & & & & & & 61 & TYLISSIPLQGAFNYK \\
\hline & & & & & & & 97 & TVQIAAVVDVIR \\
\hline & & & & & & & 31 & TVQIAAVVDVIR \\
\hline & & & & & & & 86 & ELGICPDDAAVIPIK \\
\hline & & & & & & & 59 & FYTIEILKVE \\
\hline & & & & & & & 19 & FYTIEILKVE \\
\hline \multirow[t]{5}{*}{2205} & extracellular glycoprotein & NCBI/ gi|15187164 & 14237 & 5.43 & $5(2) /$ & 110 & 11 & QELNPLK \\
\hline & lacritin precursor & & & & $21 \%$ & & 22 & SILLTEQALAK \\
\hline & & & & & & & 63 & SILLTEQALAK \\
\hline & & & & & & & 70 & SILLTEQALAK \\
\hline & & & & & & & 31 & QFIENGSEFAQK \\
\hline \multirow[t]{13}{*}{2208} & apolipoprotein A-I & gi|4557321 & 30759 & 5.56 & $17(5) /$ & 707 & 64 & VKDLATVYVDVLK \\
\hline & precursor & & & & $44 \%$ & & 87 & DLATVYVDVLK \\
\hline & & & & & & & 62 & DSGRDYVSQFEGSALGK \\
\hline & & & & & & & 93 & DYVSQFEGSALGK \\
\hline & & & & & & & 39 & DYVSQFEGSALGK \\
\hline & & & & & & & 12 & QEMSSKDLEEVK + Oxidation (M) \\
\hline & & & & & & & 13 & DLEEVK \\
\hline & & & & & & & 40 & VQPYLDDFQK \\
\hline & & & & & & & 16 & VEPLRAELQEGAR \\
\hline & & & & & & & 33 & AELQEGAR \\
\hline & & & & & & & 42 & LSPLGEEMR + Oxidation (M) \\
\hline & & & & & & & 23 & LSPLGEEMRRR + Oxidation (M) \\
\hline & & & & & & & 28 & THLAPYSDELR \\
\hline
\end{tabular}




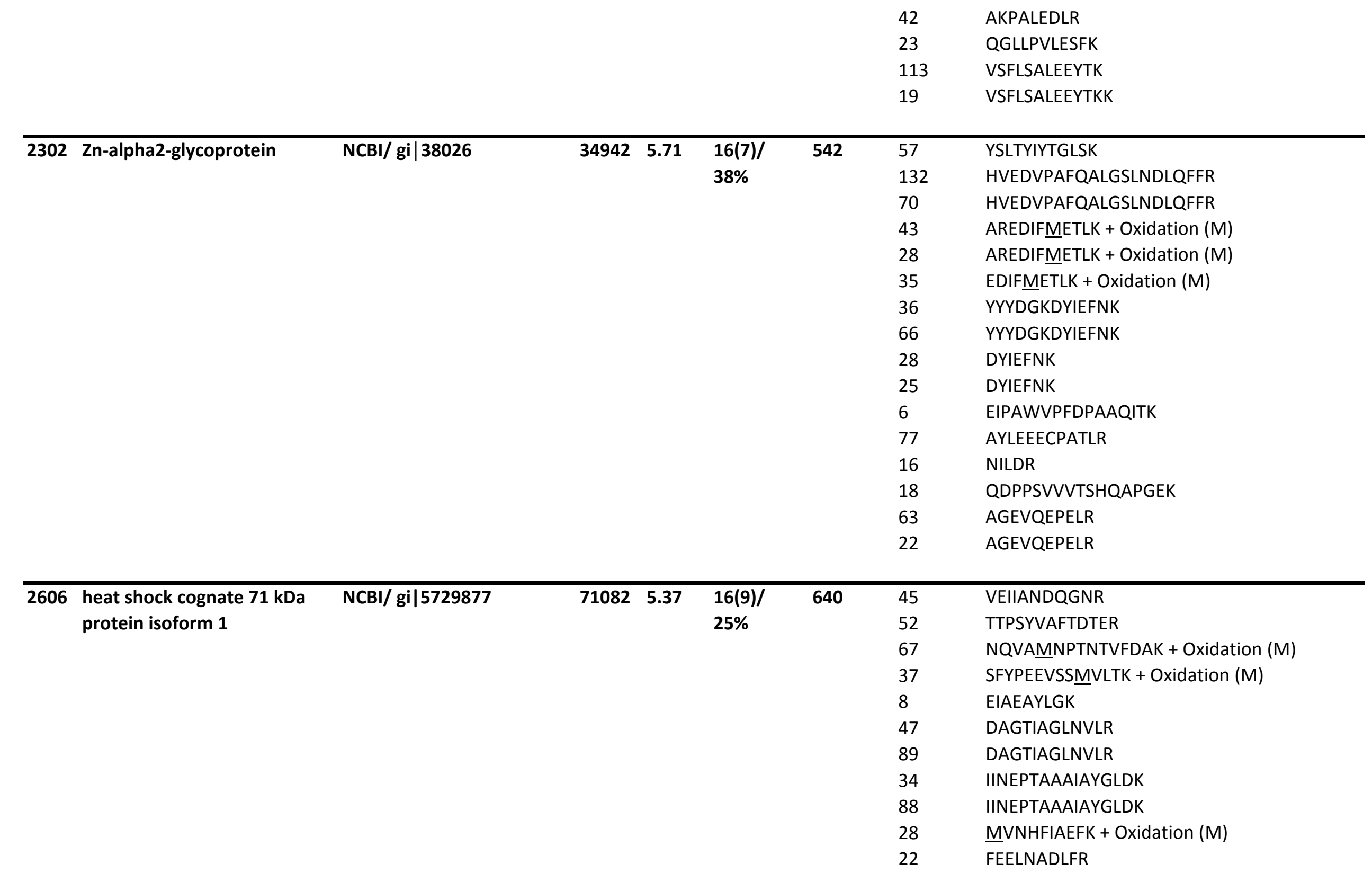







54 QGHFYGETAAVYVAVEER

62 QGHFYGETAAVYVAVEER

\begin{tabular}{|c|c|c|c|c|c|c|c|c|}
\hline 3001 & protein S100-A9 & $\begin{array}{l}\text { SwissProt/ } \\
\text { S10A9_HUMAN }\end{array}$ & 13291 & 5.71 & $\begin{array}{l}2(1) / \\
20 \%\end{array}$ & 39 & $\begin{array}{l}39 \\
7\end{array}$ & $\begin{array}{l}\text { KDLQNFLK } \\
\text { VIEHIMEDLDTNADK + Oxidation (M) }\end{array}$ \\
\hline 3106 & $\begin{array}{l}\text { proline-rich protein } 4 \\
\text { isoform } 2 \text { precursor }\end{array}$ & NCBI/gi|154448886 & 15088 & 6.5 & $\begin{array}{l}1(1) \\
11 \%\end{array}$ & 94 & 94 & FPSVSLQEASSFFQR \\
\hline 3210 & glutathione S-transferase & NCBI/ gi| 2204207 & 23595 & 5.43 & $\begin{array}{l}7(5) / \\
31 \%\end{array}$ & 339 & $\begin{array}{l}47 \\
134 \\
60 \\
123 \\
64 \\
36 \\
20\end{array}$ & $\begin{array}{l}\text { PPYTVVYFPVR } \\
\text { FQDGDLTLYQSNTILR } \\
\text { FQDGDLTLYQSNTILR } \\
\text { DQQEAALVDMVNDGVEDLR + Oxidation (M) } \\
\text { DQQEAALVDMVNDGVEDLR + Oxidation (M) } \\
\text { ALPGQLKPFETLLSQNQGGK } \\
\text { ALPGQLKPFETLLSQNQGGK }\end{array}$ \\
\hline 3301 & $\begin{array}{l}\text { lipocalin-1 isoform } 1 \\
\text { precursor }\end{array}$ & NCBI/ gi|4504963 & 19409 & 5.39 & $\begin{array}{l}23(14) / \\
52 \%\end{array}$ & 391 & $\begin{array}{l}92 \\
94 \\
58 \\
31 \\
84 \\
68 \\
73 \\
24 \\
48 \\
33\end{array}$ & $\begin{array}{l}\text { EFPEMNLESVTPMTLTTLEGGNLEAK } \\
\text { EFPEMNLESVTPMTLTTLEGGNLEAK } \\
+ \text { Oxidation (M) } \\
\text { EFPEMNLESVTPMTTTTTEGGNLEAK } \\
+2 \text { Oxidation (M) } \\
\text { EFPEMNLESVTPMTLTTLEGGNLEAK } \\
+2 \text { Oxidation (M) } \\
\text { EFPEMNLESVTPMTTLTTLEGGNLEAK } \\
+2 \text { Oxidation (M) } \\
\text { EFPEMNLESVTPMTLTTLEGGNLEAK } \\
+2 \text { Oxidation (M) } \\
\text { EFPEMNLESVTPMTTLTTLEGGNLEAK } \\
+2 \text { Oxidation (M) } \\
\text { VTMLISGR } \\
\text { VTMLISGR } \\
\text { VTMLISGR + Oxidation (M) }\end{array}$ \\
\hline
\end{tabular}




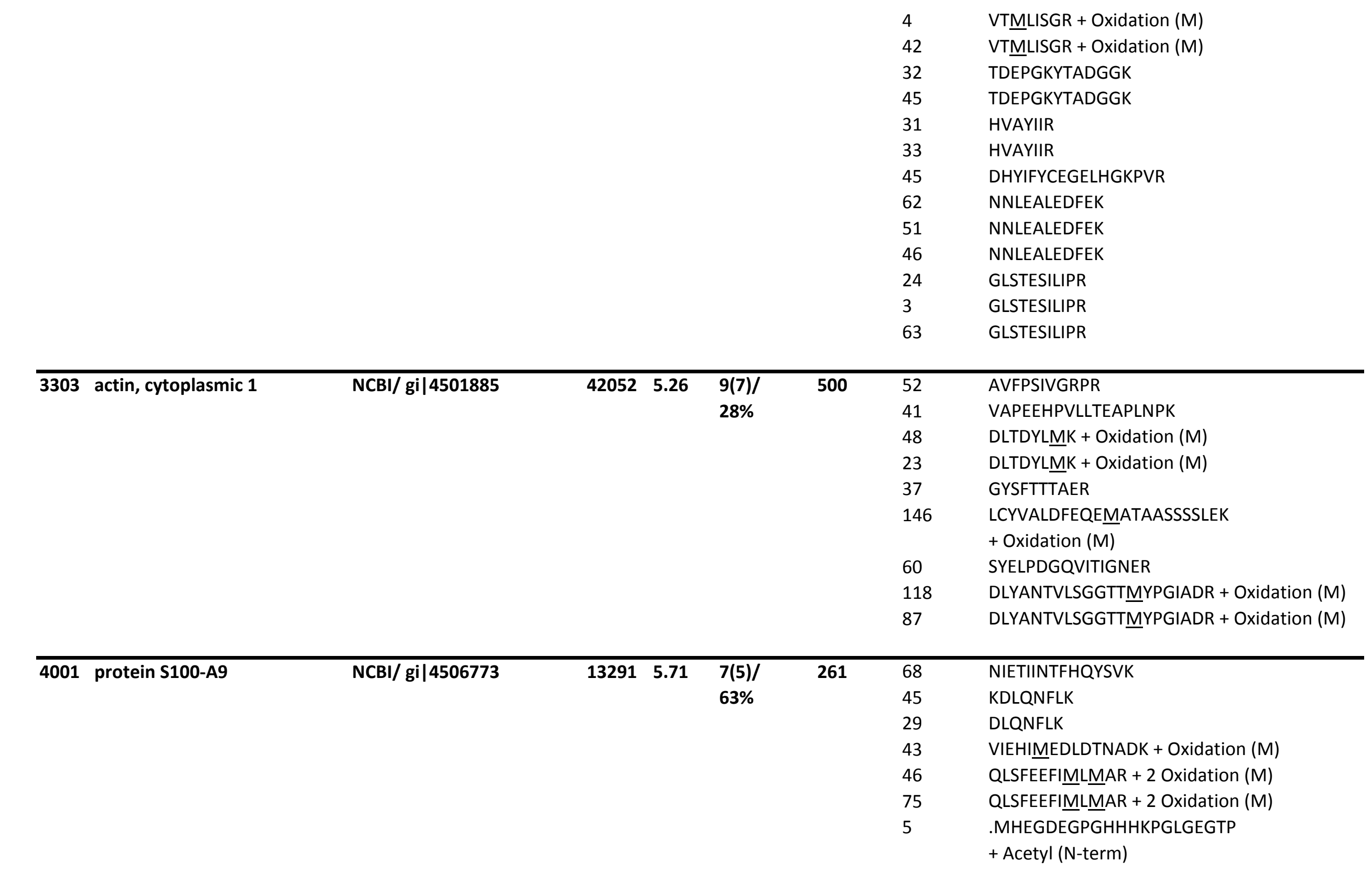




\begin{tabular}{|c|c|c|c|c|c|c|c|c|}
\hline \multirow[t]{4}{*}{4010} & protein S100-A11 & NCBI/ gi|5032057 & 11847 & 6.56 & $4(3) /$ & 194 & 81 & CIESLIAVFQK \\
\hline & & & & & $34 \%$ & & 27 & DGYNYTLSK \\
\hline & & & & & & & 86 & TEFLSFMNTELAAFTK + Oxidation (M) \\
\hline & & & & & & & 80 & TEFLSFMNTELAAFTK + Oxidation (M) \\
\hline \multirow[t]{3}{*}{4113} & proline-rich protein 4 & NCBI/ gi | 154448886 & 15088 & 6.5 & $3(3) /$ & 117 & 112 & FPSVSLQEASSFFQR \\
\hline & isoform 2 precursor & & & & $11 \%$ & & 73 & FPSVSLQEASSFFQR \\
\hline & & & & & & & 117 & FPSVSLQEASSFFQR \\
\hline \multirow[t]{4}{*}{4114} & heat shock protein beta-1 & NCBI/ gi|4504517 & 22826 & 5.98 & $3(1) /$ & 128 & 34 & AQLGGPEAAK \\
\hline & & & & & $18 \%$ & & 66 & LFDQAFGLPR \\
\hline & & & & & & & 33 & SSLSSAQADFNQLAELDR \\
\hline & & & & & & & 30 & LATQSNEITIPVTFESR \\
\hline \multirow[t]{7}{*}{5106} & heat shock protein 27 & NCBI/ gi 662841 & 22427 & 7.83 & $6(4) /$ & 278 & 20 & RVPFSLLR \\
\hline & & & & & $41 \%$ & & 70 & LFDQAFGLPR \\
\hline & & & & & & & 44 & VSLDVNHFAPDELTVK \\
\hline & & & & & & & 76 & KYTLPPGVDPTQVSSSLSPEGTLTVEAPMPK ) \\
\hline & & & & & & & & + Oxidation (M \\
\hline & & & & & & & 67 & LATQSNEITIPVTFESR \\
\hline & & & & & & & 46 & LATQSNEITIPVTFESR \\
\hline \multirow[t]{2}{*}{5111} & proline-rich protein 4 & SwissProt/ & 15088 & 6.5 & $1(1) /$ & 120 & 120 & FPSVSLQEASSFFQR \\
\hline & & PROL4_HUMAN & & & $11 \%$ & & & \\
\hline \multirow[t]{2}{*}{5112} & proline-rich protein 4 & NCBI/ gi|154448886 & 15088 & 6.5 & $2(2) /$ & 128 & 54 & FPSVSLQEASSFFQR \\
\hline & isoform 2 precursor & & & & $11 \%$ & & 128 & FPSVSLQEASSFFQR \\
\hline 5113 & fatty acid-binding protein & NCBI/ gi|4557581 & 15497 & 6.6 & $1(1) /$ & 58 & 58 & ELGVGIALR \\
\hline
\end{tabular}




\begin{tabular}{|c|c|c|c|c|c|c|c|c|}
\hline \multirow[t]{33}{*}{5701} & human serum albumin & NCBI/ gi| 3212456 & 68425 & 5.67 & $52(29) /$ & 948 & 47 & FKDLGEENFK \\
\hline & chain A & & & & $63 \%$ & & 28 & DLGEENFK \\
\hline & & & & & & & 16 & LVNEVTEFAK \\
\hline & & & & & & & 56 & LVNEVTEFAK \\
\hline & & & & & & & 89 & TCVADESAENCDK \\
\hline & & & & & & & 28 & SLHTLFGDK \\
\hline & & & & & & & 26 & SLHTLFGDK \\
\hline & & & & & & & 15 & LCTVATLR \\
\hline & & & & & & & 52 & ETYGEMADCCAK + Oxidation (M) \\
\hline & & & & & & & 22 & DDNPNLPR \\
\hline & & & & & & & 12 & YLYEIAR \\
\hline & & & & & & & 41 & YLYEIAR \\
\hline & & & & & & & 52 & RHPYFYAPELLFFAK \\
\hline & & & & & & & 68 & RHPYFYAPELLFFAK \\
\hline & & & & & & & 30 & HPYFYAPELLFFAK \\
\hline & & & & & & & 11 & AAFTECCQAADK \\
\hline & & & & & & & 59 & AAFTECCQAADK \\
\hline & & & & & & & 7 & AACLLPK \\
\hline & & & & & & & 30 & LDELRDEGK \\
\hline & & & & & & & 38 & AEFAEVSK \\
\hline & & & & & & & 33 & LVTDLTK \\
\hline & & & & & & & 23 & LVTDLTK \\
\hline & & & & & & & 74 & YICENQDSISSK \\
\hline & & & & & & & 25 & LKECCEKPLLEK \\
\hline & & & & & & & 78 & SHCIAEVENDEMPADLPSLAADFVESK \\
\hline & & & & & & & & + Oxidation (M) \\
\hline & & & & & & & 76 & DVFLGMFLYEYAR + Oxidation (M) \\
\hline & & & & & & & 63 & RHPDYSVVLLLR \\
\hline & & & & & & & 49 & RHPDYSVVLLLR \\
\hline & & & & & & & 59 & HPDYSVVLLLR \\
\hline & & & & & & & 19 & HPDYSVVLLLR \\
\hline & & & & & & & 17 & TYETTLEK \\
\hline & & & & & & & 36 & TYETTLEK \\
\hline
\end{tabular}




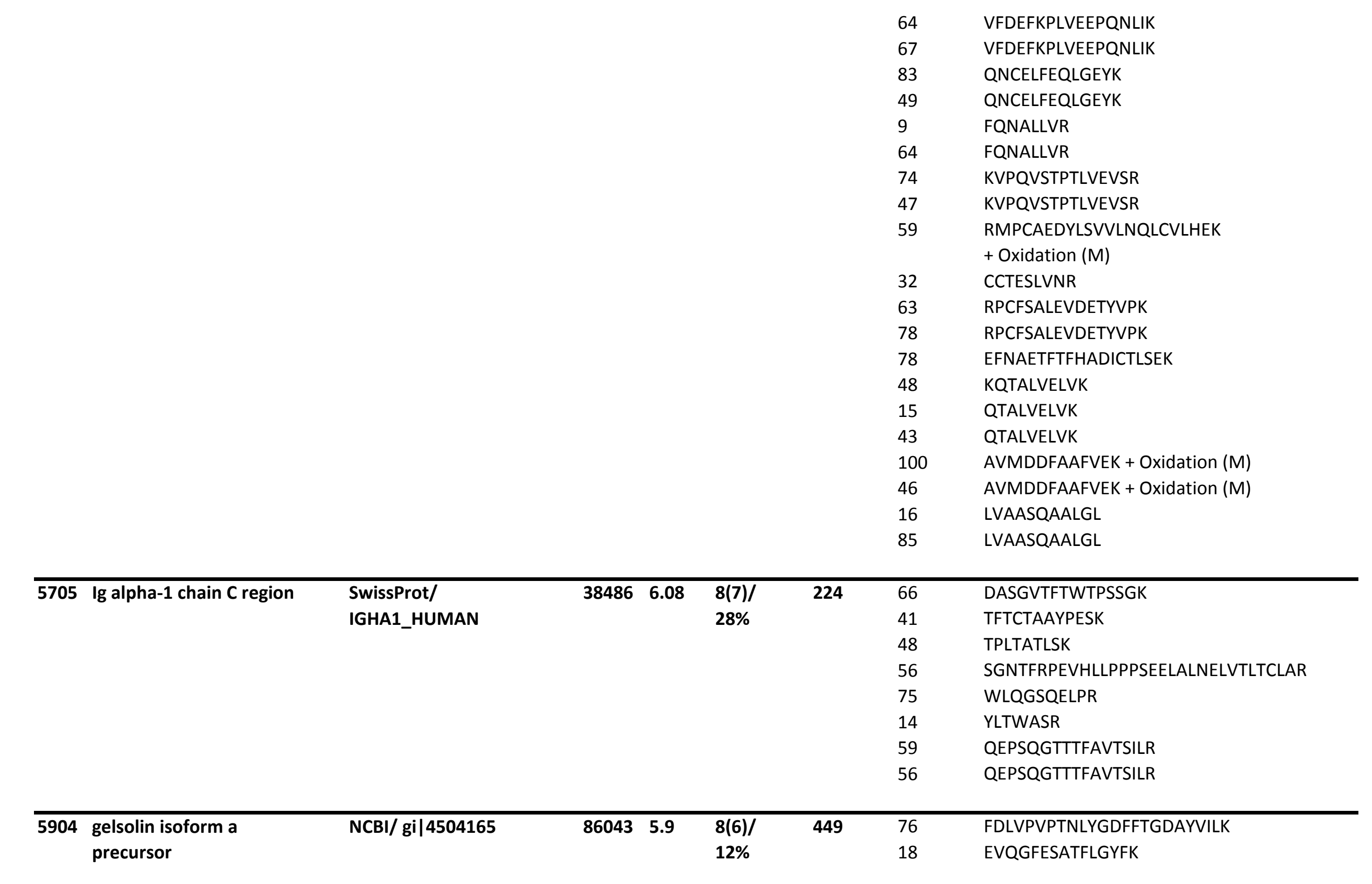




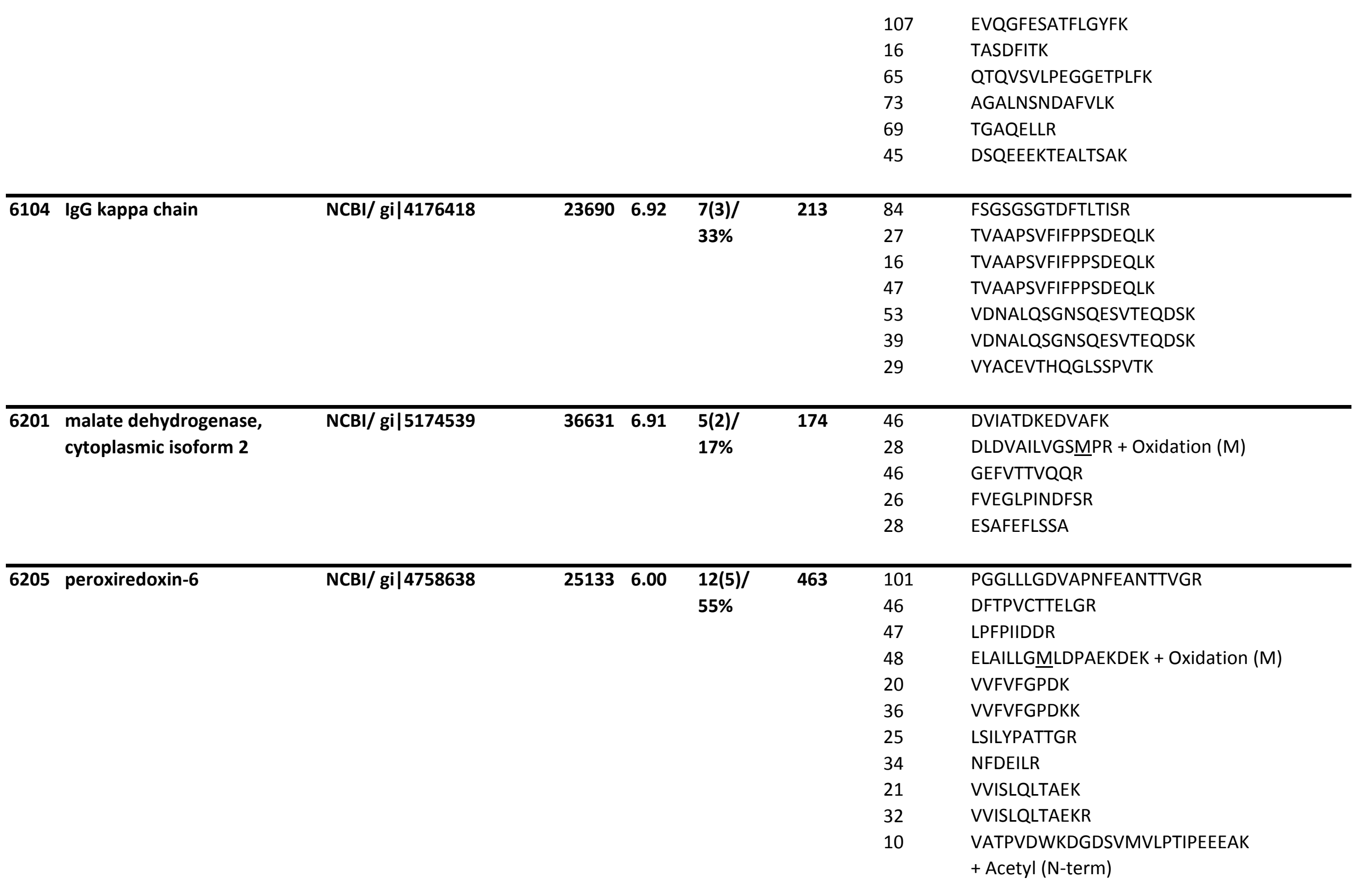




\begin{tabular}{|c|c|c|c|c|c|c|c|c|}
\hline \multirow{5}{*}{\multicolumn{2}{|c|}{6207 protein DJ-1 }} & NCBI/ gi|31543380 & 20050 & 6.33 & $5(2) /$ & 199 & 39 & GAEEMEETVIPVDVㅆR + 2 Oxidation (M) \\
\hline & & & & & $25 \%$ & & 8 & DVVICPDASLEDAK \\
\hline & & & & & & & 15 & DVVICPDASLEDAKK \\
\hline & & & & & & & 71 & GPGTSFEFALAIVEALNGK \\
\hline & & & & & & & 137 & GPGTSFEFALAIVEALNGK \\
\hline \multirow[t]{5}{*}{6302} & alpha-enolase & NCBI/ gi|4503571 & 47481 & 7.01 & $5(4) /$ & 295 & 86 & AAVPSGASTGIYEALELR \\
\hline & isoform 1 & & & & $14 \%$ & & 88 & LAMQEEFMILPVGAANFR + 2 Oxidation (M) \\
\hline & & & & & & & 44 & LAMQEEFMILPVGAANFR + 2 Oxidation (M) \\
\hline & & & & & & & 81 & VVIGMDVAASEFFR + Oxidation (M) \\
\hline & & & & & & & 40 & YISPDQLADLYK \\
\hline \multirow[t]{17}{*}{6319} & annexin A1 & NCBI/ gi|4502101 & 38918 & 6.57 & $20(13) /$ & 958 & 57 & $\begin{array}{l}\text {.AMVSEFLK.Q + Acetyl (N-term); } \\
\text { Oxidation (M) }\end{array}$ \\
\hline & & & & & $50 \%$ & & 36 & $\begin{array}{l}. \text { AMVSEFLK.Q + Acetyl (N-term); } \\
\text { Oxidation (M) }\end{array}$ \\
\hline & & & & & & & 40 & GGPGSAVSPYPTFNPSSDVAALHK \\
\hline & & & & & & & 93 & GVDEATIIDILTK \\
\hline & & & & & & & 65 & AAYLQETGKPLDETLK \\
\hline & & & & & & & 66 & ALTGHLEEVVLALLK \\
\hline & & & & & & & 49 & TPAQFDADELR \\
\hline & & & & & & & 92 & TPAQFDADELR \\
\hline & & & & & & & 90 & GLGTDEDTLIEILASR \\
\hline & & & & & & & 78 & DITSDTSGDFR \\
\hline & & & & & & & 51 & NALLSLAK \\
\hline & & & & & & & 37 & NALLSLAK \\
\hline & & & & & & & 107 & SEDFGVNEDLADSDAR \\
\hline & & & & & & & 62 & SEDFGVNEDLADSDAR \\
\hline & & & & & & & 100 & KGTDVNVFNTILTTR \\
\hline & & & & & & & 71 & GTDVNVFNTILTTR \\
\hline & & & & & & & 26 & VLDLELK \\
\hline
\end{tabular}




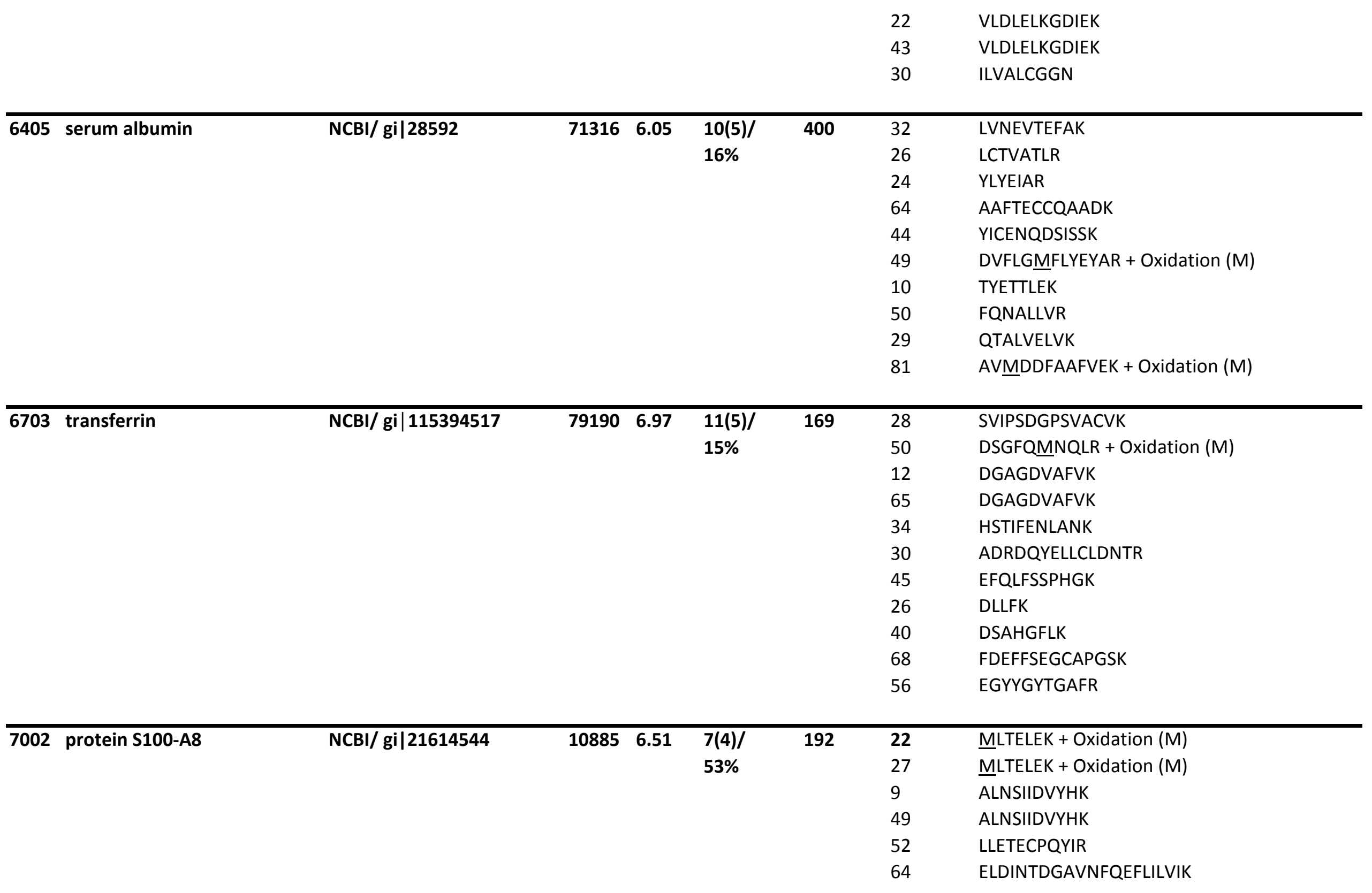




\begin{tabular}{|c|c|c|c|c|c|c|c|c|}
\hline \multirow[t]{4}{*}{$\overline{7106}$} & triosephosphate isomerase 1 & NCBI/ gi|17389815 & 26910 & 6.45 & $4(2)$ & 183 & 80 & QSLGELIGTLNAAK \\
\hline & & & & & $16 \%$ & & 26 & RHVFGESDELIGQK \\
\hline & & & & & & & 22 & HVFGESDELIGQK \\
\hline & & & & & & & 55 & IIYGGSVTGATCK \\
\hline \multirow[t]{2}{*}{7107} & keratin 1 & NCBI/ gi| 7331218 & 66149 & 8.16 & $2(1) /$ & 79 & 37 & FSSCGGGGGSFGAGGGFGSR \\
\hline & & & & & $4 \%$ & & 45 & FLEQQNQVLQTK \\
\hline \multirow[t]{3}{*}{7114} & Peroxiredoxin 5 & NCBI/ gi|15826629 & 17060 & 6.96 & $3(1) /$ & 109 & 55 & VNLAELFK \\
\hline & chain A & & & & $20 \%$ & & 18 & THLPGFVEQAEALK \\
\hline & & & & & & & 36 & LLADPTGAFGK \\
\hline \multirow[t]{13}{*}{7203} & annexin $\mathbf{A 2}$ & NCBI/ gi|4757756 & 38808 & 7.57 & $13(10 /$ & 643 & 10 & AYTNFDAERDALNIETAIK \\
\hline & isoform 2 & & & & $38 \%$ & & 17 & DALNIETAIK \\
\hline & & & & & & & 55 & DALNIETAIK \\
\hline & & & & & & & 77 & GVDEVTIVNILTNR \\
\hline & & & & & & & 52 & GVDEVTIVNILTNR \\
\hline & & & & & & & 67 & SALSGHLETVILGLLK \\
\hline & & & & & & & 53 & GLGTDEDSLIEIICSR \\
\hline & & & & & & & 60 & TNQELQEINR \\
\hline & & & & & & & 85 & TDLEKDIISDTSGDFR \\
\hline & & & & & & & 72 & RAEDGSVIDYELIDQDAR \\
\hline & & & & & & & 92 & AEDGSVIDYELIDQDAR \\
\hline & & & & & & & 28 & SLYYYIQQDTK \\
\hline & & & & & & & 47 & ALLYLCGGDD \\
\hline \multirow[t]{5}{*}{7321} & isocitrate dehydrogenase 1 & NCBI/ gi|89573979 & 42091 & 6.19 & $4(3) /$ & 227 & 66 & ATDFVVPGPGK \\
\hline & & & & & $19 \%$ & & 33 & VEITYTPSDGTQK \\
\hline & & & & & & & 41 & VTYLVHNFEEGGGVAMGMYYNQDK \\
\hline & & & & & & & & + 2 Oxidation (M) \\
\hline & & & & & & & 87 & ELAFFANALEEVSIETIEAGFMTK \\
\hline
\end{tabular}


+ Oxidation (M)

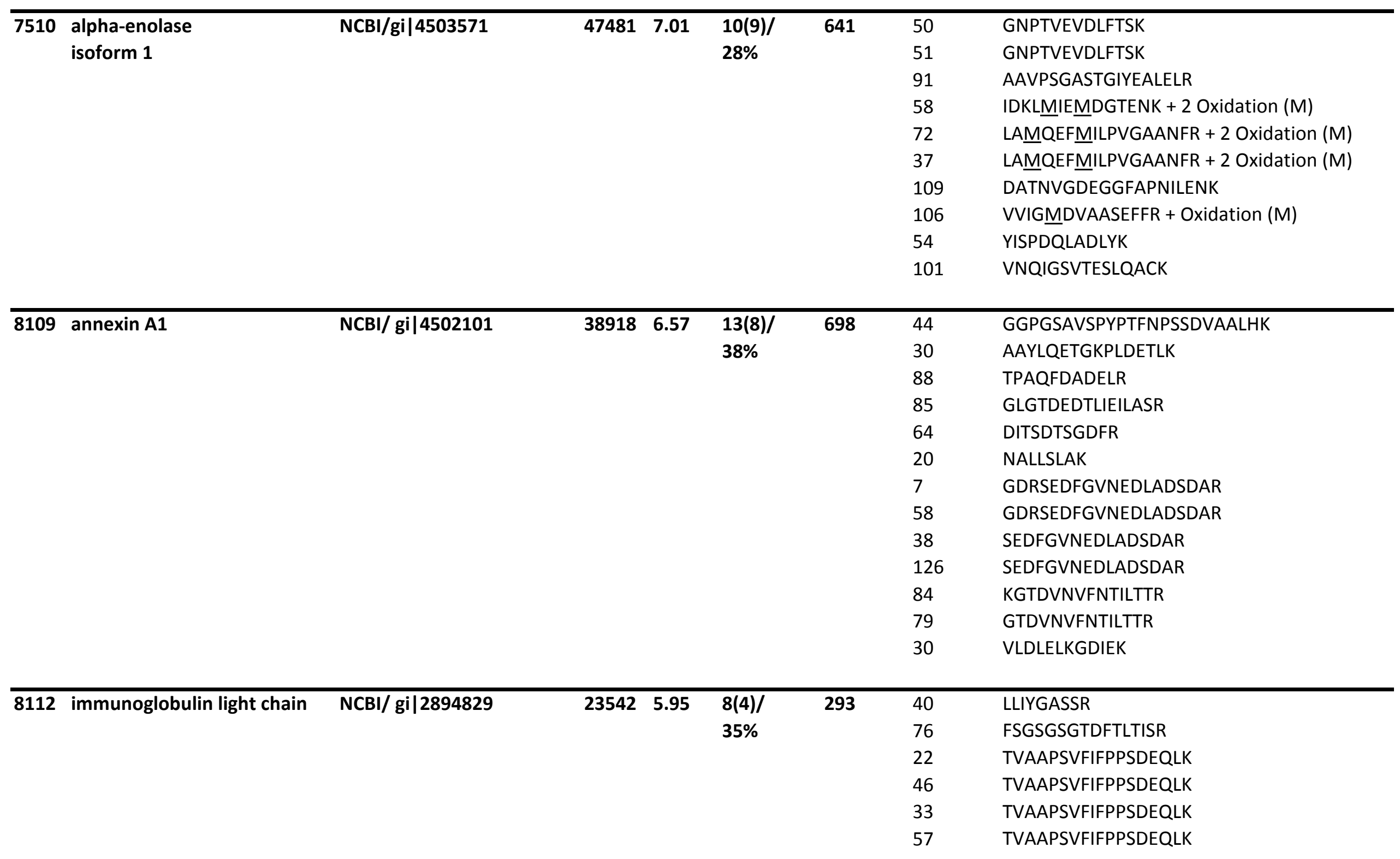




\begin{tabular}{|c|c|c|c|c|c|c|c|}
\hline & & & & & & $\begin{array}{l}113 \\
8\end{array}$ & $\begin{array}{l}\text { VDNALQSGNSQESVTEQDSK } \\
\text { VDNALQSGNSQESVTEQDSKDSTYSLSSTLTLSK }\end{array}$ \\
\hline 8201 beta-2 microglobulin & NCBI/gi|34616 & 12905 & 5.77 & $\begin{array}{l}3(1) / \\
38 \%\end{array}$ & 107 & $\begin{array}{l}56 \\
24 \\
27\end{array}$ & $\begin{array}{l}\text { SNFLNCYVSGFHPSDIEVDLLK } \\
\text { VEHSDLSFSK } \\
\text { VNHVTLSQPK }\end{array}$ \\
\hline 8301 phosphoglycerate kinase 1 & NCBI/gi|4505763 & 44985 & 8.3 & $\begin{array}{l}3(1) / \\
6 \%\end{array}$ & 92 & $\begin{array}{l}62 \\
10 \\
30\end{array}$ & $\begin{array}{l}\text { VLNNMEEIGTSLFDEEGAK + Oxidation (M) } \\
\text { VLPGVDALSNI } \\
\text { VLPGVDALSNI }\end{array}$ \\
\hline 8502 serum albumin & SwissProt/ALBU_HUMAN & 71317 & 5.92 & $\begin{array}{l}10(5) / \\
16 \%\end{array}$ & 165 & $\begin{array}{l}32 \\
26 \\
24 \\
64 \\
44 \\
49 \\
10 \\
50 \\
29 \\
81\end{array}$ & $\begin{array}{l}\text { LVNEVTEFAK } \\
\text { LCTVATLR } \\
\text { YLYEIAR } \\
\text { AAFTECCQAADK } \\
\text { YICENQDSISSK } \\
\text { DVFLGMFLYEYAR + Oxidation (M) } \\
\text { TYETTLEK } \\
\text { FQNALLVR } \\
\text { QTALVELVK } \\
\text { AVMDDDFAAFVEK + Oxidation (M) }\end{array}$ \\
\hline 8801 lactoferrin & NCBI/ gi|186833 & 80228 & 8.56 & $\begin{array}{l}54(38) / \\
53 \%\end{array}$ & 2249 & $\begin{array}{l}75 \\
82 \\
57 \\
54 \\
62 \\
36 \\
51 \\
73 \\
114 \\
70 \\
69\end{array}$ & $\begin{array}{l}\text { SVQWCTVSQPEATK } \\
\text { DSPIQCIQAIAENR } \\
\text { DSPIQCIQAIAENR } \\
\text { ADAVTLDGGFIYEAGLAPYK } \\
\text { ADAVTLDGGFIYEAGLAPYK } \\
\text { ADAVTLDGGFIYEAGLAPYK } \\
\text { ADAVTLDGGFIYEAGLAPYK } \\
\text { ADAVTLDGGFIYEAGLAPYK } \\
\text { ADAVTLDGGFIYEAGLAPYK } \\
\text { ADAVTLDGGFIYEAGLAPYK } \\
\text { ADAVTLDGGFIYEAGLAPYK }\end{array}$ \\
\hline
\end{tabular}




ADAVTLDGGFIYEAGLAPYK
ADAVTLDGGFIYEAGLAPYK
LRPVAAEVYGTER
THYYAVAVVK
THYYAVAVVK
KGGSFQLNELQGLK
GGSFQLNELQGLK
GGSFQLNELQGLK
FFSASCVPGADK
GQFPNLCR
GQFPNLCR
CAFSSQEPYFSYSGAFK
DGAGDVAFIR
DGAGDVAFIR
DGAGDVAFIR
ESTVFEDLSDEAER
EDAIWNLLR
EDAIWNLLR
FQLFGSPSGQK
FQLFGSPSGQK
DLLFK
DSAIGFSR
DSAIGFSR
IDSGLYLGSGYFTAIQNLR
IDSGLYLGSGYFTAIQNLR
VVWCAVGEQELR
GEADAMSLDGGYVYTAGK
GEADAMSLDGGYVYTAGK + Oxidation (M)
SQQSSDPDPNCVDRPVEGYLAVAVVR
RSDTSLTWNSVK
RSDTSLTWNSVK
SDTSLTWNSVK
FDEYFSQSCAPGSDPR
SNLCALCIGDEQGENK
SE







24

9501 chain A, C3b in complex with a C3b specific Fab
713726.82

16(10)/

$35 \%$
DISLSDYK

KQGGLGPMNIPLVSDPK + Oxidation (M)

QGGLGPMNIPLVSDPK + Oxidation (M)

TIAQDYGVLK

ADEGISFR

GLFIIDDK

QITVNDLPVGR

LVQAFQFTDK

LVQAFQFTDK

15

$$
37
$$

LESEETMVVLEAHDAQGDVPVTVTVHDFPGK

+ Oxidation (M)

VVLVSLQSGYLFIQTDK

VVLVSLQSGYLFIQTDK

TIYTPGSTVLYR

TVMVNIENPEGIPVK + Oxidation (M)

AYYENSPQQVFSTEFEVK

EYVLPSFEVIVEPTEK

KVEGTAFVIFGIQDGEQR

VLLDGVQNPR

YFKPGMPFDLMVFVTNPDGSPAYR

+2 Oxidation (M)

VPVAVQGEDTVQSLTQGDGVAK

TELRPGETLNVNFLLR

TELRPGETLNVNFLLR

YYTYLIMNK + Oxidation (M)

EPGQDLVVLPLSITTDFIPSFR

EPGQDLVVLPLSITTDFIPSFR 